\title{
State of the Art Review -
}

\section{Pulmonary Manifestations of Immune Deficiency Diseases}

\author{
Juan L. Sotomayor, MD, ${ }^{1}$ Steven D. Douglas, $M D,{ }^{2}$ and Robert W. Wilmott, $M D^{1}$
}

\section{INTRODUCTION}

The defense of the respiratory system against infection involves a complex interplay of the humoral immune system and the cellular immune system with complement and phagocytic cells. The respiratory tract is an important portal of entry for infection, and it is therefore not surprising that many immune deficiencies present initially with a respiratory infection. Thus, pediatric pulmonologists must be familiar with the pulmonary manifestation of immune deficiency. In this article we review current concepts concerning pulmonary disease in children with primary immune deficiency diseases and acquired immune deficiency syndrome (AIDS).

\section{HUMORAL IMMUNE DEFICIENCIES IgA Deficiency}

IgA is the principal immunoglobulin present in external secretions of the upper respiratory tract. Although all immunoglobulin classes are represented in secretions, the proportion of $\mathrm{IgG}$ to IgA rises as sampling proceeds peripherally toward the alveoli. Thus, the amount of $\mathrm{IgG}$ exceeds that of $\operatorname{IgA}$ in bronchoalveolar lavage fluid (BAL). ${ }^{1}$ The major source of $\operatorname{IgA}$ is local synthesis, although transudation from plasma does contribute a minor amount. ${ }^{2}$ Secretory IgA is synthesized by lymphoid tissue located in the lamina propria and the submucosa of the airway. Although circulating IgA in serum is predominantly monomeric, luminal $\operatorname{IgA}$ (secretory $\operatorname{Ig} \mathrm{A}$ ) is secreted by plasma cells as two monomers linked by a $\mathbf{J}$ chain. The secreted dimer is further modified by the overlying epithelial cells by the addition of a secretory chain (Fig. 1). Secretory chains render the IgA relatively resistant to enzymatic digestion by proteolytic enzymes at mucosal surfaces. IgA exists principally as two subclasses, $\operatorname{Ig} \mathrm{A}_{1}$ and $\operatorname{Ig} \mathrm{A}_{2}$. Normally, serum contains $80-$ $90 \% \operatorname{Ig} \mathrm{A}_{1}$ and $10-20 \% \operatorname{IgA_{2}}$, whereas in secretions $\operatorname{Ig} \mathrm{A}_{2}$ levels are almost equal to $\operatorname{Ig} A_{1} \cdot{ }^{3}$ The significance of this difference in subclass proportions is unknown.

The function of $\operatorname{IgA}$ is considered to be more important in the upper airway than in the lower airway. It is thought to bind to complex inhaled antigens, thus preventing their adherence to mucosal surfaces. IgA agglutinates microorganisms and neutralizes toxins, viruses, and enzymes. IgA may also activate the alternative pathway of complement, although its function as an opsonizing (phagocytosis enhancing) antibody in bacterial diseases is limited. In summary, the major function of $\operatorname{IgA}$ is to bind and clear antigens from the mucosal surfaces of the airway. ${ }^{4}$

Isolated IgA deficiency occurs in about $1 / 700$ individuals, and it is the most common primary immune deficiency. In normal individuals, the serum IgA concentration is less than $5 \mathrm{mg} / 100 \mathrm{~mL}$ at birth and does not reach adult levels until age 8 or 9 years; therefore, IgA deficiency cannot be diagnosed reliably until that age. ${ }^{5}$ Children with isolated IgA deficiency persist with IgA levels less than $5 \mathrm{mg} / 100 \mathrm{~mL}$ while other immunoglobulin levels are normal, and cellular immunity is intact. The normal ontogeny of B-cell development is shown in Figure 2 , and the basic defect in IgA deficiency appears to be an abnormality of terminal differentiation of immature B lymphocytes. ${ }^{6}$ Usually both serum and secretory $\operatorname{lgA}$ are

From the Division of Pulmonary Medicine, Department of Pediatrics, Wayne State University School of Medicine, Children's Hospital of Michigan, Detroit, Michigan; ${ }^{1}$ Divison of Allergy-Immunology-Bone Marrow Transplantation, Department of Pediatrics, University of Pennsylvania School of Medicine, Children's Hospital of Philadelphia, Philadelphia, Pennsylvania. ${ }^{2}$

Received August 29, 1988; accepted for publication September 15, 1988.

Address correspondence and request for reprints to Dr. R. W. Wilmott, Director, Division of Pulmonary Medicine, Children's Hospital of Michigan, 3901 Beaubien Boulevard, Detroit, MI 48201. 

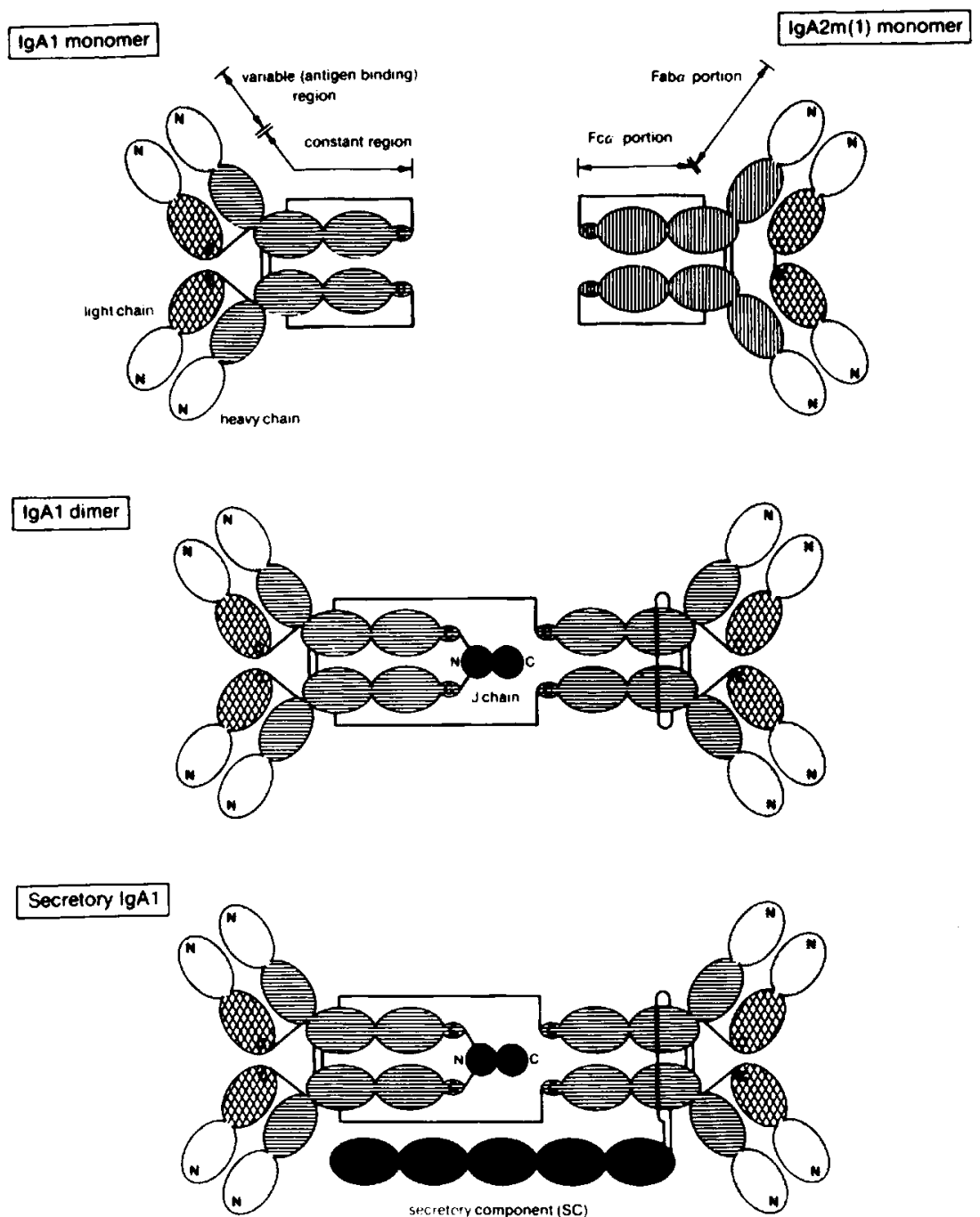

Fig. 1. IgA molecule in serum and secretions. (Figure reproduced with permission, from the Annual Review of Immunology, Vol. 4, (c) 1986, by Annual Reviews, Inc.)

absent, although it is possible to have absence of serum $\operatorname{IgA}$ and normal levels of secretory $\operatorname{IgA} .{ }^{7}$ One patient has been described with an absence of secretory piece and secretory IgA who presented with intestinal candidiasis and had no respiratory symptoms. ${ }^{8}$ Only one family with $\operatorname{IgA} \mathrm{A}_{2}$ deficiency has been reported. ${ }^{9}$ Both forms of $\operatorname{IgA}$ deficiencies are very rare.

Isolated IgA deficiency is associated with many different systemic diseases. Allergic disorders, especially food allergies, and autoimmune disorders such as rheumatoid arthritis and systemic lupus erythematosus are common. Recurrent respiratory infections such as otitis, pharyngitis, sinusitis, and pneumonitis occur with equal frequency and affect approximately $40 \%$ of IgA-deficient individuals. ${ }^{10}$ An association with recurrent croup has also been reported. ${ }^{11}$ The spectrum of sinopulmonary disease in $\operatorname{IgA}$ deficiency tends to be milder than in other antibody deficiencies. Pulmonary function is usually normal, and, although recurrent lower respiratory tract infections can occur, the development of bronchiectasis is rare. ${ }^{12}$ Cases of pulmonary hemosiderosis associated with IgA deficiency have been reported although the significance of this association is unclear. ${ }^{13,14} \mathrm{~A}$ link between $\operatorname{IgA}$ and $\operatorname{IgE}$ production has been suggested by Polmer et al. who observed that patients with associated $\operatorname{IgA}$ and IgE deficiency had a lower incidence of respiratory tract disease, while those who produce IgE had more respiratory tract symptoms. ${ }^{15}$ Alteration of $\mathrm{IgE}$ production and regulation may help explain why these IgA-deficient patients may have a higher incidence of allergies and autoimmune diseases.

There are limited data on the types of infection seen in IgA deficiency (although a viral propensity is typical). It is interesting that both $S$. pneumoniae and Hemophilus influenzae are important pathogens in normal children. These bacteria may produce IgA proteases that cleave 


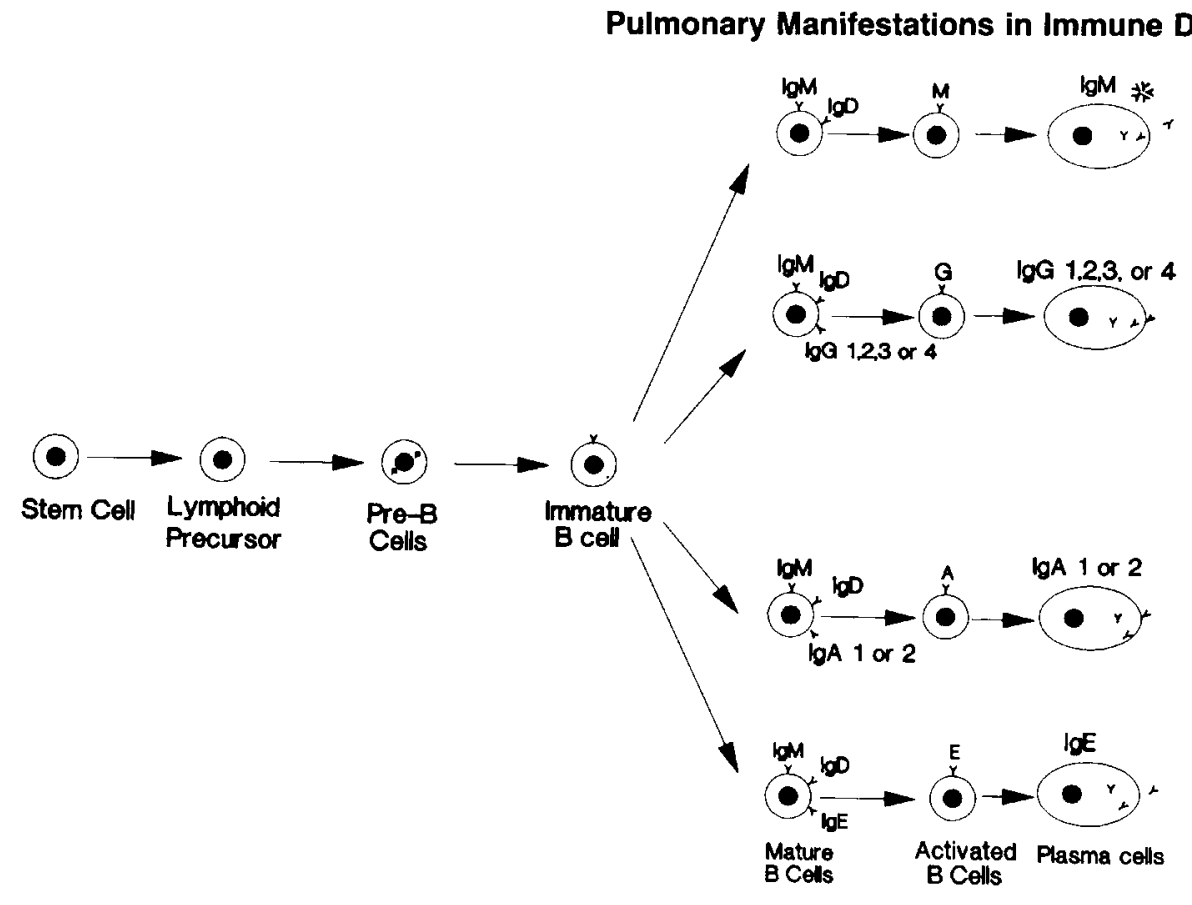

Fig. 2. Normal B-cell maturation.

$\operatorname{Ig} A_{1}$ but not $\operatorname{Ig} \mathrm{A}_{2}$ or $\operatorname{IgG}$. In addition to proteases, these organisms may release exo- and endoglycosidases that cleave the carbohydrate side chains of $\operatorname{Ig} \mathrm{A}_{1}$. Therefore, the potential exists for bacteria that disrupt IgA to have a selective advantage over other bacteria that inhabit the upper airway. ${ }^{16}$

The prognosis for patients with IgA deficiency is generally excellent, and patients usually have a normal life span, although the course may be altered by associated disease processes. Currently, there is no treatment for isolated $\operatorname{IgA}$ deficiency. Patients with complete absence of IgA who receive gamma globulin (or other blood products) may develop anaphylaxis because of the development of antibodies to $\operatorname{IgA}{ }^{17}$ Intravenous $\operatorname{IgA}$ replacement therapy would not deliver adequate antibodies to the mucosal surface, the primary site of action. In summary, although IgA deficiency can be associated with different diseases, most patients are asymptomatic and completely healthy.

\section{X-Linked Agammaglobulinemia (XLA)}

XLA was first described by Bruton in 1954, and it is characterized by markedly depressed serum antibody levels. IgM, IgG, and IgA levels are below the $95 \%$ confidence limit for age- and race-matched controls (IgG levels are usually less than $100 \mathrm{mg} / \mathrm{dL}$ ). ${ }^{18}$ The basic defect in this disorder is a block in pre-B-cell to B-cell differentiation (Fig. 2). Normal numbers of pre-B cells are present in the bone marrow, and the total number of circulating T-cells is usually increased. The thymus is normal in XLA and cellular immunity appears intact, whereas lymphatic tissue is hypoplastic. Antibody levels are depressed, and the ability to make antigen-specific functional antibodies is impaired. ${ }^{19}$

The clinical manifestations of XLA are those of antibody deficiency. Chronic otitis media, rhinitis, and pharyngitis are common. Cervical adenitis occurs despite a paucity of lymphoid tissue. Many patients show sinusitis radiographically, and the maxillary and ethmoid sinuses are most commonly affected, followed by the frontal sinuses.

Wheezing is a common symptom in XLA owing to increased mucopurulent secretions as well as increased airway reactivity. Chronic bronchitis, which does not occur in normal children, is present in almost all patients with XLA. Bacterial pneumonias may be lobar, lobular, unilateral, or bilateral, and involvement of lower, rightmiddle, or left upper (lingula) lobes is typical. Bronchiectasis is a common complication of recurrent pulmonary infections. In one small series, $30 \%$ of patients with XLA eventually developed bronchiectasis that usually involved the lower lobes. ${ }^{20}$ Bronchograms show cylindrical dilatation of the airways and mildsaccular bronchiectasis. In severe bronchiectasis, extensive fibrosis with destruction of the architecture may occur. Mild digital clubbing may develop as well as chronic atelectasis, pleural effusions, and lung abscesses. ${ }^{21}$

A wide range of pulmonary function abnormalities has been observed. In our experience, children treated early and aggressively with antibiotics and immunoglobulin replacement show only mild small airway obstruction. Severely affected children may progress to a mixed defect with restrictive and obstructive changes. ${ }^{20}$

The most common organisms found in lung infections 
include pneumococcus, nontypable $H$. influenzae, $S$. aureus, and $N$. meningococcus. Echovirus infection can affect the central nervous system and the gastrointestinal tract, but it is not usually a pulmonary pathogen. Pneumocystis carinii may present early in life in children with XLA, although it is more commonly associated with cellular immune defects. The mechanism for susceptibility to $P$. carinii in humoral deficiency is unknown ${ }^{22}$ since the normal host defense mechanisms for $P$. carinii are not defined.

Treatment of patients with XLA includes use of appropriate antibiotics based on the results of cultures, pulmonary toilet, and intravenous gammaglobulin. It has been suggested that high-dose gammaglobulin titrated to maintain serum IgG concentrations greater then 500 $\mathrm{mg} / \mathrm{dL}$ improves lung function. ${ }^{23}$ The prognosis is generally good with early institution of aggressive therapy. A small subgroup of these children develops lymphoreticular malignancies or persistent echovirus infection and the prognosis of this subgroup is much worse. Chronic sinopulmonary problems contribute to persistent morbidity, although they do not affect life expectancy. ${ }^{18}$

\section{Common Variable Immunodeficiency (CVID)}

CVID is a heterogeneous disorder characterized by recurrent bacterial infections in previously healthy people. The onset is usually in the 2 nd or 3 rd decade of life, and respiratory infections are a prominent symptom. ${ }^{24}$ Immunologically, these children, or young adults, have a decrease of all immunoglobulin classes and variableTcell function. There may be an increased or decreased number of B-cells. Failure of terminal differentiation of cultured B-cells into plasma cells in response to antigenic or mitogenic stimulation is the most common laboratory abnormality ${ }^{19}$ (Fig. 2).

There are major differences between CVID and XLA: 1) CVID is associated with a familial tendency with equal male:female proportions; 2) XLA becomes apparent in infancy, while CVID is more common in the 2nd or 3rd decade of life; 3 ) the course of CVID is usually milder, which may reflect its later onset and memory of the immune system from early development; 4 ) there is a higher incidence of autoimmune disorders in CVID ${ }^{25} ; 5$ ) there is a higher incidence of gastrointestinal disorders in CVID than in XLA ${ }^{26}$; 6) there are associated T-cell defects in CVID, which do not occur in XLA. ${ }^{27}$

Recurrent upper and lower respiratory tract infections are common manifestations of CVID in children. In one study, recurrent respiratory infections occurred in 6/30 children before age 1 year. ${ }^{25}$ Upper respiratory infections, especially otitis and sinusitis, are present in almost all patients. Mastoid abnormalities were seen in all eight patients examined in one series. ${ }^{28}$ Recurrent pneumonias affect $87 \%$ of patients, and bronchiectasis eventually develops in $30-40 \%$ of patients. ${ }^{29,30}$ Common radio- graphic findings include air trapping, increased linear markings, pleural abnormalities, and bullous lesions in the lower lobes. ${ }^{31} S$. pneumoniae, $H$. influenzae, and $S$. aureus are the most common infecting organisms. Mycoplasma, pertussis, and pseudomonas infections have also been described. ${ }^{32}$

Pulmonary function abnormalities in CVID are variable as both obstructive and restrictive changes can develop. Most patients have only mild changes, and in one study, $36 \%$ remained completely normal..$^{29,31}$ The prognosis seems to be good if early intervention is undertaken.

An unusual association between CVID and sarcoidlike granulomas in the lung has been reported. The pathogenesis of this disorder is uncertain, and it is unclear whether this represents a subset of children with sarcoid or a subset of CVID patients with a T-cell regulatory disorder. ${ }^{33}$

Nodular lymphoid interstitial pneumonitis has also been reported as an uncommon complication of CVID. ${ }^{34-36}$ Restrictive PFT changes, increased interstitial markings on chest roentgenograms, and arterial hypoxemia may suggest this diagnosis. Histologically, a predominance of T-lymphocytes and a paucity of lymphoid germinal centers are found. Prednisone has been useful as the treatment of choice in children with nodular lymphoid hyperplasia.

Antibody deficiency with elevated sweat chloride concentrations was reported in three children with CVID, which raised the question of cystic fibrosis. ${ }^{37}$ One of the three grew Pseudomonas aeruginosa from sputum cultures; however, that patient had a normal pancreatic stimulation test. The other two patients had no other stigmata of cystic fibrosis, and all three subsequently had normal repeat sweat tests. Treatment with gammaglobulin improved their clinical and radiographic abnormalities.

\section{IgG Subclass Deficiency}

$\operatorname{lgG}$ is the major immunoglobulin class sampled in broncho-alveolar lavage (BAL), and it is the major humoral defense mechanism of the lower airway. $\operatorname{IgG}$ is differentiated into four subclasses based on the constant region of the heavy chain $\left(\psi_{1}-\psi_{4}\right)$. IgG subclasses differ in their amino acid sequences in the hinge region and at the $\mathrm{C}$ terminus. ${ }^{38}$ In addition to minor sequence and physicochemical differences, IgG subclasses also possess different effector functions. These functions are based on receptor capabilities and binding specificity. For instance, $I g G_{1}$ and $\operatorname{IgG}_{3}$ activate the classical complement pathway, while $\mathrm{IgG}_{2}$ does so weakly and $\mathrm{IgG}_{4}$ not at all. $\mathrm{IgG}_{2}$ activates the alternative pathway of complement. $\mathrm{IgG}_{4}$ binds to mast cells and may be important as a mediator of allergy, functioning as a reaginic antibody. $\mathrm{IgG}_{1}$ constitutes about $65 \%$ of the total $\mathrm{IgG}, \mathrm{IgG}_{2}$ is 
$20-25 \%, \operatorname{IgG}_{3}$ is $6-10 \%$, and $\operatorname{IgG}_{4}$ is $5 \%$ or less. $\mathrm{IgG}_{1}$ and $\mathrm{IgG}_{3}$ reach adult levels by age 1 year, while $\mathrm{IgG}_{2}$ and $\mathrm{IgG}_{4}$ reach adult levels more slowly.

IgG subclass specificities are important determinants of opsonic capability for different organisms. Responses to protein antigens such as diphtheria and tetanus are by $\operatorname{IgG}_{1}$ and $\mathrm{IgG}_{3}$ antibodies, and this response is dependent on T-cell interaction. Responses to polysaccharides including encapsulated bacterial organisms such as $H$. influenzae and $S$. pneumococcus are usually of the $\mathrm{IgG}_{2}$ and $\mathrm{IgG}_{4}$ subclasses. These responses tend to be $\mathrm{T}$-cell independent, although this concept may not be completely valid as T-cell products may be important for B-cell differentiation and production of the antibodies. ${ }^{39}$

Umetsu et al. studied 20 children with isolated IgG subclass deficiency: 12 with $\operatorname{IgG}_{2}$ deficiency, 5 with isolated $\mathrm{IgG}_{3}$ deficiency, and 3 with combined $\mathrm{IgG}_{2}$ and $\mathrm{IgG}_{3}$ deficiency. All patients suffered from recurrent otitis and sinusitis. Eleven of the children suffered from at least one episode of pneumonia, and ten had recurrent asthma. Although no organisms were isolated, most children with $\mathrm{IgG}_{2}$ deficiency had defective antibody responses to $H$. influenzae. ${ }^{40}$

A study of six adult patients with combined IgG subclass deficiency demonstrated impaired lung function. The $\mathrm{FEV}_{1}$ and single-breath nitrogen washout test were the most significantly impaired values. ${ }^{41}$ Ten of 37 nonallergic children with chronic chest symptoms caused by asthma, recurrent infections, and cough were found to have subclass deficiency. ${ }^{42}$ Other studies have extended these findings to include an increased frequency of $\mathrm{IgA}$ deficiency associated with $\mathrm{IgG}_{2}$, and $\mathrm{IgG}_{4}$ deficiencies. ${ }^{43}$ Early studies detailing an increased risk of isolated IgA deficiency with recurrent infections may have been inaccurate because IgG subclass levels were not measured. Oxelius ${ }^{44}$ reported that low or immeasurable $\mathrm{IgG}_{2}$ levels were found in seven of 37 patients with IgA deficiency. All seven had frequent respiratory tract infections in contrast to 11 healthy adults with IgA deficiency found by population screening. Thus, it is unclear whether the increased risk of infection in earlier studies was really due to the IgA deficiency. Selective $\mathrm{IgG}_{4}$ deficiency is also highly associated with severe sinopulmonary infections. ${ }^{45}$

Most children with a subclass deficiency have normal total IgG levels. Clinically these patients present in a manner similar to hypogammaglobulinemia patients, except that the symptoms are usually milder. Current therapy includes gammaglobulin, immunizations, and antibiotics. It may not be essential to prescribe gammaglobulin in all cases, especially if children do not have severe infections or if they are in good general health. The decision to commence replacement therapy should be individualized, and in some instances its use can be restricted to times of infection. Fresh frozen

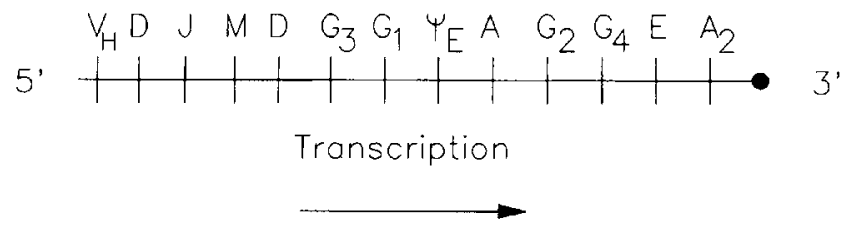

Fig. 3. Relative position of immunoglobulin genes on chromosome 14.

plasma infusions may be useful, especially in children with $\mathrm{IgG}_{4}$ deficiency. ${ }^{46}$

Disorders with predominately defects of cell-mediated immunity such as ataxia telangiectasia may also present with IgG subclass deficiency. Recurrent upper respiratory infections are common, and IgA, IgE, and IgG subclass levels are reduced. ${ }^{15}$ These combined deficiencies may be explained by the relative position and proximity of the genes controlling heavy chain transcription (Fig. 3). Transcription from the VDJ portion of chromosome 14 proceeds so that class switching and expression of IgG occurs in an orderly sequence. Looping out of a portion of the gene may explain the combinations of subclass deficiencies seen.

\section{Transient Hypogammaglobulinemia of Infancy (THI)}

THI may not be a primary immunodeficiency so much as an accentuation of the physiologic decline in serum immunoglobulin concentrations after birth. ${ }^{18}$ In the newborn, there is a general decline of fetal IgG levels reaching a nadir in 3 to 6 months. Then IgM, followed by IgG, and $\operatorname{IgA}$ progressively increase in response to antigenic stimulation.

In THI a deficiency of $\operatorname{IgG}$ is present with normal levels of $\operatorname{IgM}$ and $\operatorname{IgA}$. Circulating B-cells are normal, and antigen-specific responses (functional antibodies) are intact. A functional deficiency in T-helper cells has been reported, which may account for delayed IgG production. ${ }^{47}$

Two subgroups of THI have been recognized clinically: 1) a clinically healthy group of infants with immunodeficient relatives, 2) a group of infants with recurrent infections generally characterized by recurrent middle ear infections, bronchitis, or unexplained fevers. ${ }^{48,49}$ Generally, the prognosis for these infants is excellent with general recovery of immunologic function by 1-2 years of age. Most initial infections are not severe, and gammaglobulin therapy is not indicated. The treatment of choice is supportive care with use of appropriate antibiotics.

\section{CELLULAR DEFICIENCIES}

\section{Severe Combined Immune Deficiency (SCID)}

The severe combined immune deficiency is not a single disorder but a heterogeneous group of diseases with 
multiple patterns of expression. They can be inherited as $\mathrm{X}$-linked or autosomal recessive conditions. Cell-mediated immune deficiency with T-cell abnormalities is profound, and therefore infections with opportunistic organisms are a hallmark of the disease. Children with SCID present with failure to thrive, severe recurrent bacterial infections such as otitis, sepsis, or pneumonia, and chronic diarrhea with secondary malabsorption. Skin disorders may predominate and are exacerbated by intractable, chronic candidiasis. Children with SCID do not reject foreign cells, and infants are susceptible to graftversus-host disease from maternally derived lymphocytes. ${ }^{19}$ Chronic hepatitis and encephalopathy from infection with viruses such as cytomegalovirus can be lethal. Herpes virus infections such as varicella may be devastating.

The immunologic findings in SCID include marked lymphopenia, cutaneous anergy, inability to reject transplants, and a general lack of $\mathrm{T}$ - and B-cell function. Immunoglobulin levels and antibody formation are low to absent, and proliferative responses to mitogens such as pokeweed and concanavalin are virtually absent. Natural killer (NK)-cell function is variable. Lymph nodes are usually hypoplastic, although enlargement can also be seen. The most constant anatomic abnormality is severe dysplasia of the thymus. The thymus is usually small and has poor corticomedullary distinction, absent Hassall's corpuscles, and reduced numbers of thymocytes; normal thymic epithelium is usually present. ${ }^{18}$

Some other immune deficiencies are clinical variations of SCID and for the purpose of this discussion are generally similar. Nezeloff's syndrome is similar to "classic" SCID except for near-normal immunoglobulin levels. However, specific antibody responses are dysfunctional. Combined immunodeficiency can also be associated with two enzyme deficiencies of the purine salvage pathway: adenosine deaminase (ADA) deficiency and purine nucleoside phosphorylase (PNP) deficiency. The mechanism of selected toxicity to the immune system by products of the purine salvage pathway is generally unknown. ADA deficiency is transmitted as an autosomal recessive condition. It might account for up to $50 \%$ of the autosomal recessive cases of SCID seen, and its incidence is about 1 in $200,000 .^{50}$ ADA deficiency can sometimes be distinguished from "classic" SCID because of the presence of rib cage abnormalities such as rachitic rosary, condro-osseous dysplasia, and occasional Hassall's corpuscles in the thymus. PNP deficiency is rarer than ADA deficiency, with only 22 patients reported. ${ }^{51,52}$ PNP deficiency has no skeletal abnormalities but the thymus in these children has rudimentary Hassall's corpuscles. These patients may be mistaken for having Nezeloff's syndrome because of similar laboratory findings. Combined immune deficiencies can be found in some patients with short-limbed dwarfism, and their presentation may be similar to "classic" SCID although the disease is usually milder. Combined immune deficiency is occasionally associated with leukopenia and is called reticular dysgenesis. These children generally do poorly as they have a severe deficiency of several arms of the immune system.

Bacterial infections are important in SCID as in humoral immunodeficiencies; however, the propensity for these children to acquire unusual opportunistic infections is high, and pulmonary infections may be the presenting symptom. Leggiadro et al. ${ }^{53}$ found that 31 of 115 patients $(27 \%)$ diagnosed with SCID had at least one episode of infection with $P$. carinii. An early study investigating $P$. carinii in childhood found that in 29 patients infected with this microorganism, under 1 year of age, 15 had SCID. ${ }^{54}$ Although $P$. carinii is an important pathogen, viral infections of the lung are also prevalent. In one recent study of ten SCID patients, 13 episodes of pneumonia were observed. The paramyxovirus group accounted for 7 of the 13 episodes. Parainfluenza type III infections were the most common and severe, although type I and II can also occur. This type of infection has been reported by many authors. ${ }^{55-59}$ Other viruses that are commonly found include fatal RSV infection, ${ }^{60}$ adenovirus, ${ }^{61}$ and, less commonly CMV, coxsackie, and possibly papova virus. ${ }^{55}$ Children with paramyxovirus and RSV pneumonia exhibit unusual giant cells on tissue specimens. ${ }^{62,63}$ One case of fatal disseminated Legionella pneumophila has been described in an infant with SCID. ${ }^{64}$

The prognosis for these patients prior to the availability of bone marrow transplant was grave. Bone marrow transplant offers the best hope, but the morbidity remains high. ${ }^{65}$ Fetal liver and thymus transplants or extracts have been used with variable results. In ADA deficiency about $50 \%$ of patients respond to erythrocyte transfusions, which replace the missing enzymes. ${ }^{66}$ Specific therapy is indicated for opportunistic infections such as $P$. carinii. Parainfluenza 3, once acquired, is particularly serious, and aerosolized Ribavirin has been tried without success. Ribavirin has been therapeutic in one child with SCID and RSV infection. ${ }^{67}$ One case report indicated that high-dose gamma globulin replacement may be useful in adenovirus infection. ${ }^{61}$ Bactrim or pentamidine remains the treatments of choice for $P$. carinii infections, while erythromycin may be useful for Legionella $s p$. if diagnosed early in the course of the disease.

\section{Acquired Immune Deficiency Syndrome (AIDS)}

The acquired immune deficiency syndrome has become progressively more common in children over the last decade. From early reports questioning the existence of AIDS in pediatrics ${ }^{68}$ with only 13 reported cases, to well over 500 pediatric cases under 13 years of age in 1988 and a predicted 3,000 to be afflicted by 1991 , the 
AIDS epidemic is the most formidable pediatric immunodeficiency. ${ }^{69}$ Infection with human immunodeficiency virus (HIV) and a depletion of CD4 helper/inducer lymphocytes is characteristic of the disease. The exact mechanism of selective tropism and killing of CD4 cells is unknown. Other cell types including monocytemacrophages and glial cells are also infected. B-cells, mononuclear phagocytes, natural killer cells, and cytotoxic T-cells are all affected as their interaction with CD4 lymphocytes is central to the immune response, and these defects are responsible for the susceptibility to opportunistic infections. ${ }^{70}$ High-risk children for AIDS include those who are products of intravenous drug abusers or their partners, prostitutes, female sexual partners of bisexual men, and hemophiliacs who have received contaminated blood products. ${ }^{71}$

Pulmonary disease is prominent in both adults and children with AIDS, and frequently it is the first manifestation of disease. Recurrent bacterial infections and pneumonias, in spite of a polyclonal hypergammaglobulinemia, are well documented in pediatric AIDS and are the result of poor specific antibody production. ${ }^{72}$ The bacterial pathogens most commonly implicated include $H$. influenzae, S. pneumoniae, group B Streptococcus, and Branhamella catarrhalis. ${ }^{73}$ Defective humoral immunity may be more severe in children than adults because of the lack of memory B-lymphocytes, which have not yet developed. Opportunistic infections are very common, and the most common organism is $P$. carinii. In one recent study of 29 children who presented with diffuse bilateral disease, 14 had $P$. carinii infection. ${ }^{74}$ Clinically, these children may present with an insidious onset of fever, tachypnea, shortness of breath, and nonproductive cough. Their chest $\mathrm{X}$-rays may range from normal to having alveolar and interstitial infiltrates. Blood gas measurements frequently show hypoxia with an elevated alveolar-arterial difference $\mathrm{P}_{(\mathrm{A}-\mathrm{a}) \mathrm{O}_{2}}$. Diffusing capacity for carbon monoxide $\left(\mathrm{D}_{\mathrm{LCO}}\right)$ is frequently reported lower than $80 \%$ predicted value in adult AIDS with $P$. carinii, although this has not been evaluated in pediatric AIDS. ${ }^{75}$ Infections with Mycobacterium aviumintracellulare and Mycobacterium tuberculosis are also common. In adults with AIDS, Mycobacterium aviumintracellulare rarely causes serious lung disease and is commonly associated with a nonspecific "wasting syndrome" consisting of fever, anorexia, weight loss, night sweats, weakness, and diarrhea. ${ }^{76}$ A minority of these patients may have associated chest pain and hemoptysis. ${ }^{77} M$. tuberculosis can present with similar symptoms, although lymphadenopathy may be more prominent. Chest X-rays may be normal or may have a miliary pattern; however, cavitation and upper lobe disease are rare. ${ }^{76,77}$ Less common infections include Legionella pneumophila, herpes, toxoplasmosis, cytomegalovirus, and fungal infections, especially
TABLE 1-Pulmonary Involvement in Adult Patients With AIDS

\begin{tabular}{|c|c|c|}
\hline & $\begin{array}{c}\text { From } \\
\text { Murray } \\
\text { et al. }{ }^{75} \\
(\mathrm{n}=441) \\
(\%)\end{array}$ & $\begin{array}{c}\text { From } \\
\text { Marchevsky } \\
\text { et al }{ }^{80} \\
(\mathrm{n}=70) \\
(\%)\end{array}$ \\
\hline \multicolumn{3}{|l|}{ Infections $\mathbf{a}^{\mathrm{a}}$} \\
\hline P. carinii & 85 & 67 \\
\hline M. avium-intracellulare & 17 & 6 \\
\hline tuberculosis & 4 & \\
\hline CMV & 17 & 6 \\
\hline Legionella & 4 & 0 \\
\hline Pyogenic bacteria & 2 & 8.5 \\
\hline Crytococcus neoformans & 2 & 1.5 \\
\hline $\begin{array}{l}\text { Other fungi } \\
\text { (Candida, Histoplasma, Aspergillus) }\end{array}$ & 2 & 7 \\
\hline Herpes simplex & $<1$ & 0 \\
\hline Toxoplasmi gondii & $<1$ & 3 \\
\hline Kaposi sarcoma & 8 & 6 \\
\hline Pulmonary hemorrhage & - & 6 \\
\hline Lymphoma & - & 3 \\
\hline Adult resp. distress syndrome & - & 21 \\
\hline Lymphoid interstitial pneumonitis & - & 3 \\
\hline
\end{tabular}

${ }^{a}$ Two or more may be in the same patient.

Cryptococcus neoformans, which is becoming an important etiologic agent in adults. ${ }^{78}$ Kaposi's sarcoma, involving the lung, has not yet been reported in children, although it is common in adults with AIDS. Table 1 shows the distribution of findings in adult patients. ${ }^{75,79,80}$

Although infection is an important finding, lymphocytic interstitial pneumonitis and/or pulmonary lymphoid hyperplasia (PLH) is a common finding in pediatric AIDS. Rubinstein et al., found that $6 / 15$ children with pediatric AIDS has lymphocytic interstitial pneumonitis (LIP) by open lung biopsy. ${ }^{81}$ These children presented with both a nodular and interstitial pattern throughout the lung parenchyma extending to the periphery. Hilar and mediastinal lymphadenopathy are common. Clinically, children with PLH complicating AIDS appear less toxic than children with acute infections. They may have generalized lymphadenopathy, salivary gland enlargement, digital clubbing, and minor auscultatory abnormalities on physical examination. Fever and tachypnea are not prominent symptoms. $P_{(A-a) 0}$, values are significantly lower in PLH (median 41 torr) than in those patients with $P$. carinii (median 160 torr). Concomitant infections occur, and an association between probable pulmonary lymphoid hyperplasia and EBV infection has been suggested. It is possible that an acute infection or reactivation of EBV triggers an exaggerated lymphoid response. EBV-specific DNA has been detected in patients with pulmonary lymphoid hyperplasia ${ }^{82}$ and increased EBV titers are a common finding. ${ }^{81} \mathrm{LDH}$ isoenzymes are generally not high in PLH in contrast to $P$. carinii infections 
where LDH levels may be increased (mean of 906 IU/L) ${ }^{81,83}$ PLH is not common in adult AIDS although LIP has been reported. ${ }^{84,85}$ Pathologically, lymphocytic interstitial pneumonitis is characterized by an interstitial accumulation of mature lymphocytes, plasma cells, and macrophages disseminating into the alveolar septae and peribronchiolar areas. Vascular involvement occurs but without necrosis or angio-destruction. Pulmonary lymphoid hyperplasia differs slightly from LIP in that there are nodules corresponding to aggregates of mononuclear cells. Large nodules containing germinal centers and a thick wall venule are characteristic. ${ }^{86,87}$ LIP may represent one stage of pulmonary lymphoid hyperplasia. Gallium scanning has been reported to be useful in diagnosing infections in adult AIDS, but in children with PLH/LIP the pattern is indistinguishable from that of $P$. carinii. $^{88}$

The prognosis of patients with pediatric AIDS is unknown, although acute infections bode poorly. ${ }^{89}$ Steroid therapy may have a place in the treatment of LIP/PLH. ${ }^{90}$ $P$. carinii infections can be treated with trimethoprimsulfamethoxazole (TMP-SMX) or pentamidine, but adverse drug reactions to TMP-SMX are common in adult AIDS. ${ }^{91}$ The efficacies of these two drugs are similar with a $60-80 \%$ response initially and a poorer prognosis for subsequent episodes. No benefit is seen with a combination of the two drugs. New forms of therapy under investigation include using corticosteroids, inhaled pentamidine, dapsone-TMP combinations, eflornithine-trimetrexate combinations, and pyrimethamine-sulfadoxine combinations. Prophylactic treatment with TMP-SMX is useful to prevent $P$. carinii, and inhaled pentamidine is under investigation in adults where the preliminary data are encouraging. ${ }^{76}$ Intravenous gamma globulin and antibiotic therapy are often used for acute bacterial infections, and long-term gamma globulin therapy should be considered. ${ }^{72,83}$ No effective therapy for Mycobacterium avium-intracellulare has been established, although various antituberculous regimens are being evaluated. ${ }^{92}$

\section{DiGeorge Syndrome (DS)}

The DiGeorge Syndrome is due to defective development of the embryonic 3rd and 4th pharyngeal pouches during the 6th to 8th week of gestation. Complete and partial forms of DiGeorge syndrome based on the extent of immunological and clinical involvement have been recognized.$^{93}$ In its full clinical form, the DS is characterized by symptomatic hypoparathyroidism and hypocalcemia, absent or ectopic thymus, and congenital heart defects such as interrupted aortic arch or truncal abnormalities. Other described abnormalities include CNS abnormalities, eye defects, cleft lip, cleft palate and uvula, other facial dysmorphias, diaphragmatic abnormalities, hydronephrosis, malrotation of the gut, and imperforate anus. ${ }^{94}$ Chromosomal abnormalities in DS have been re- cently reported.$^{95}$ Immunological abnormalities include abnormal T-cell function and responses and, less commonly, B-cell abnormalities. ${ }^{96,97}$ In its most severe form, DS has an extremely poor prognosis, which is most often related to cardiac maldevelopment and failure to thrive.

The most common abnormality found on chest examination in DS includes absent thymus on the roentgenogram. Specific congenital abnormalities of the pulmonary system have not been reported. Infections of the lung may include CMV, $P$. carinii, Klebsiella, and $P$. aeruginos $a^{32}$ and are generally part of a systemic process.

Treatments that have been tried with varying success include fetal thymus gland transplantation and thymic hormone injections. A successful bone marrow transplant has been recently reported in a 28 -week female infant with $21 / 2$ year follow-up to date. ${ }^{98}$

\section{Ataxia Telangiectasia (AT)}

The AT syndrome was extensively reviewed by McFarlin et al. ${ }^{99}$ and is characterized by cerebellar ataxia and the development of ocular and cutaneous telangiectasia. Liver, renal, and endocrine abnormalities have also been reported. Immune deficiencies and associated recurrent sinopulmonary infections are common complications. Initial estimates for the frequency of involvement of the sinopulmonary system ranged from $45 \%$ to $81 \%$, but more recently it was suggested that these figures are overestimates. ${ }^{100}$ The etiology is unknown, but lymphocytes show an increased number of chromosomal abnormalities and an increased rate of chromosomal breakage when exposed to ionizing radiation. ${ }^{101}$ Elevated alpha fetoprotein can be found in these patients, which may be suggestive of chromosomal abnormalities. ${ }^{102}$ Development of lymphoreticular malignancies is common and adversely affects prognosis.

The immunological abnormalities in ataxia telangiectasia are variable. One of the most common is selective IgA deficiency. Oxelius found that out of 22 patients studied, 10 had IgA deficiency, and almost all had very low or borderline low serum $\operatorname{IgG}_{2}$ levels, although total IgG was normal. ${ }^{103}$ Other investigators have also documented low or dysfunctional IgG antibody. Levels of IgM are usually normal but may be very high. ${ }^{104} \operatorname{IgE}$ is decreased or absent in about $80 \%$ of patients. ${ }^{15,105} \mathrm{~T}$-cell defects are variable and are usually manifested as absent delayed hypersensitivity responses and reduced responses to mitogens, such as phytohemagglutinin (PHA). Graft rejection may also be impaired and T-cell helper function is sometimes abnormal. ${ }^{106}$ The early literature on increased sinopulmonary infections probably relates to unrecognized IgG subclass deficiency and increased susceptibility to bacterial infection with development of bronchiectasis and chronic lung disease. Ther- 
apy with gamma globulin may be useful, but overall prognosis is poor because of progressive neurological deterioration or the development of malignancies. ${ }^{107}$

\section{Wiskott Aldrich Syndrome (WAS)}

The Wiskott Aldrich syndrome is a rare X-linked recessive disorder characterized by eczema, thrombocytopenia, and recurrent infections. The usual clinical presentation is a bleeding episode within the first 6 months of life secondary to thrombocytopenia. ${ }^{108}$ In addition to thrombocytopenia, the platelets are abnormally small and have a shortened survival period. ${ }^{109}$ Eczema usually develops in the 1st year of life. Recurrent respiratory tract infections are due to a combination of $\mathrm{B}$ - and $\mathrm{T}$-cell defects. The T-cell defects may result in anergy, lymphopenia, impaired graft rejection, and variable responses to T-cell mitogens. ${ }^{10,111}$ The most common Bcell defects include the inability to form antibodies to polysaccharide antigens, whereas protein antibodies can be normal. A common immunoglobulin profile seen is very increased $\operatorname{IgE}, \operatorname{IgA}$, and $\operatorname{IgG}$ levels with a reduced concentration of IgM, and isohemagglutinins, which are blood type IgM antibodies, are usually absent. ${ }^{112}$ Hypercatabolism of immunoglobulins may also occur in this syndrome. ${ }^{113}$ Cooper et al. found that $11 / 18$ of patients with WAS had pneumonias, and $15 / 18$ had recurrent URIs. ${ }^{110}$ The most common infections are bacterial, but infections with $P$. carinii and herpes also occur. ${ }^{114}$

The prognosis is grave for patients with WAS who usually die in the 1 st or 2 nd decades of life. Most die from bleeding, infection, or lymphoreticular malignancy. Thirty percent of documented deaths are from respiratory infections. ${ }^{115}$ Successful bone marrow transplants have been reported, ${ }^{116}$ and transfer factor has also been tried with some initial success. ${ }^{117}$

\section{COMPLEMENT DEFICIENCIES}

The complement system is a cascade of serum proteins that when activated mediate host defenses and inflammation in an orderly, integrated manner. ${ }^{118}$ The complement system comprises two pathways that eventually converge: the classical and the alternative pathways (Fig. 4).

The classical pathway is usually activated by antigenantibody complexes. IgM, $\operatorname{IgG}_{1}, \operatorname{IgG}_{2}$, and $\operatorname{IgG}_{3}$ form immune complexes, which can activate the pathway. The alternative pathway can be activated by lipopolysaccharides, IgA complexes, and certain other foreign cell and particle surfaces. In general, naturally occurring activators of the alternative pathway have absent or diminished amounts of sialic acid on their surface. ${ }^{119}$ Most bacteria and plants lack sialic acids on their surfaces and are, therefore, efficient promoters of activation.

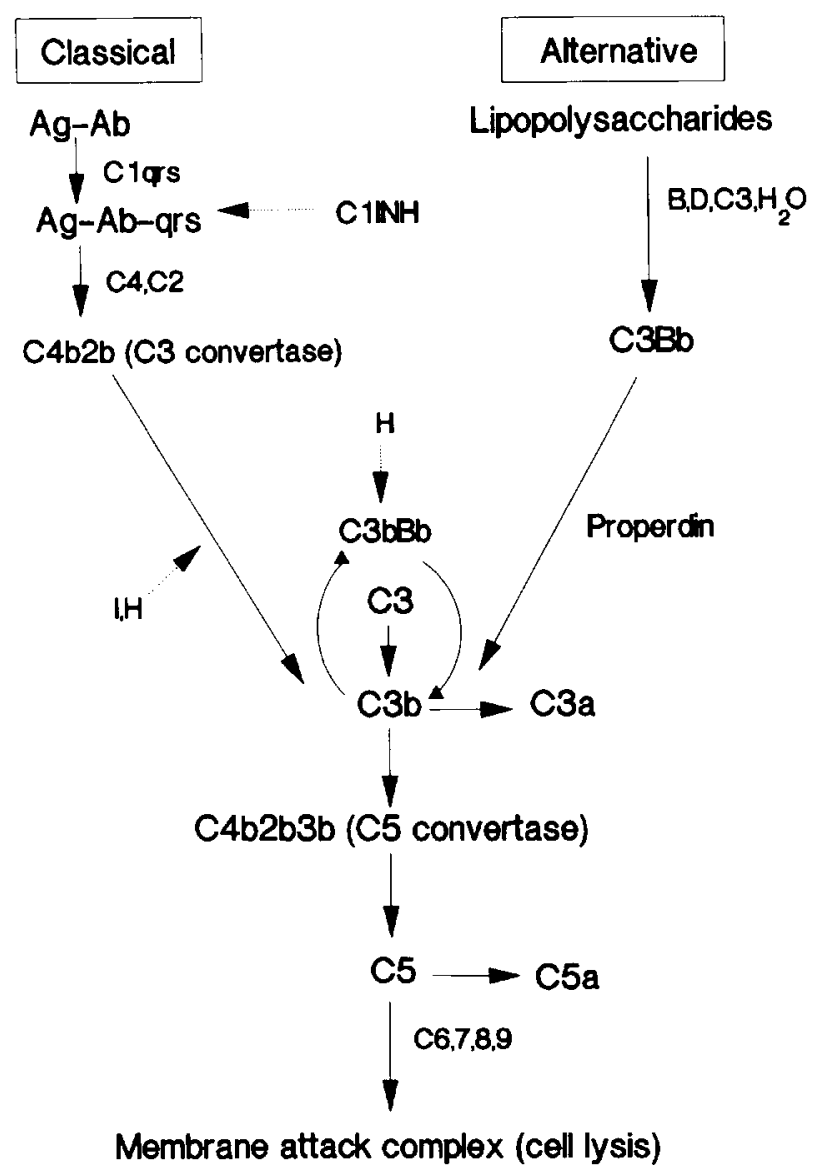

Fig. 4. Complement pathways.

The ultimate function of both pathways is the formation and assembly of $\mathrm{C} 5 \mathrm{~b}, 6,7,8$, and $\mathrm{C} 9$, the membrane attack complex, which will lead to cell death by cytolysis. However, during the normal progression of the pathway cleavage proteins such as $\mathrm{C} 3 \mathrm{a}, \mathrm{C} 5 \mathrm{a}$, and $\mathrm{C} 3 \mathrm{~b}$ are released that have important immunological functions such as chemotaxis, opsonization, and anaphylatoxin activity. There are also regulatory proteins such as factors $\mathrm{H}$ and $\mathrm{I}$ that inhibit or promote the activation of the cascade.

Complement deficiency is usually due to a defect in one of the components of either pathways. It can manifest clinically in one of three ways: 1) recurrent infections, 2) glomerulonephritis, or 3) a collagen vascular disorder such as lupus, dermatomyositis, or vasculitis. The early complement protein deficiencies are strongly associated with lupus, glomerulonephritis, and other rheumatic diseases. ${ }^{120} \mathrm{Cl}$ deficiencies are characterized by bacterial meningitis, although pneumonia has also been described. ${ }^{121} \mathrm{C} 1 \mathrm{r}$ deficiency with liver abscesses and pneumonia, complicated by pneumatoceles and empyema, was recently described. ${ }^{122} \mathrm{Cl}$ esterase inhibitor deficiency, although not associated with an immu- 
nodeficiency, is characterized by recurrent attacks of angioedema. It can begin in adulthood or childhood, and its major clinical manifestation is of periodic nonpitting, nonpruritic edema, usually after minor trauma. The major respiratory manifestation is that of laryngeal edema, which can be fatal. One case of recurrent pulmonary edema has been reported. ${ }^{123}$ Three forms are recognized, two of which are inherited as autosomal dominant conditions and are associated with a dysfunctional or absent protein level, and one that is acquired and is usually associated with an underlying malignancy and a dysfunctional protein. ${ }^{124}$ The pathogenesis of swelling is feit to be due to consumption of $\mathrm{C} 4, \mathrm{C} 2, \mathrm{C} 1$ substrates and the generation of bradykinin since $\mathrm{Cl}$ esterase inhibitor is a major inhibitor of activated Hagemann factor and kallikrien. ${ }^{125} \mathrm{C} 4$ deficiency is characterized more by autoimmune disorders than by infections. $\mathrm{C} 2$ deficiency is closely linked with both autoimmune disorders and systemic pyogenic infections, and its deficiency has been reported to be twice as common as any other complement disorder. C3 deficiency, which is important in both the classical and the alternative pathways, is the most severe complement deficiency, manifested by both recurrent infections and autoimmune disorders. It is extremely rare, and only 15 patients have been reported. ${ }^{126}$ The loss of the opsonization function of this protein may contribute to the severity of this disease. Infections seen commonly include otitis, pneumonias, sepsis, meningitis, periodontitis, and osteomyelitis. The lung may be secondarily affected by systemic infection. The most common infecting organisms are $S$. pneumoniae, $N$. meningitidis, and less commonly Klebsiella, E. coli, and S. pyogenes. ${ }^{121}$ C5 deficiency may be more complex than deficiency of other proteins because it has other functions such as chemotaxis and anaphylatoxin activ- ity. ${ }^{121,127,128}$ Experimentally, C5-deficient mice have decreased lung clearance of $S$. aureus. ${ }^{129}$ Other studies have shown that total decomplementation in rats markedly increases the number of bacteria in the lungs, as well as the severity of the lung infection induced by intratracheal inoculation of bacteria. ${ }^{130}$ However, these findings may not apply to all organisms. ${ }^{131}$ The late complement deficiencies (C5C9) result in impairment of both serum bactericidal and cytolytic activity. These individuals suffer from recurrent infection caused chiefly by $N$. meningitidis and $N$. gonorrhea. There is also a sporadic association with autoimmune disease. Lung involvement is not usually a major problem in the late complement deficiencies.

Although bacterial infections predominate in complement deficiency states, 9 of 242 patients reported had Mycobacterium tuberculosis. Six of these patients had an early complement deficiency. ${ }^{121}$

Deficiencies of the alternative pathway are extremely rare. Properdin factor deficiency can present as pneumonia but is mainly associated with $N$. meningitidis infec- tion. Factors $\mathrm{H}$ and $\mathrm{I}$ are regulatory proteins of both pathways, and deficiencies are similar to $\mathrm{C} 3$ deficiency with recurrent pyogenic infections and autoimmune diseases. Pneumonias with encapsulated bacteria such as $H$. influenzae and $S$. pneumoniae are common. ${ }^{128}$

Most deficiencies of complement are inherited in an autosomal recessive manner except properdin deficiency, which is X-linked. Deficient states are associated with the homozygous condition, although heterozygous deficiencies of $\mathrm{C} 4$ and $\mathrm{C} 2$ are sometimes associated with clinical disease. ${ }^{127}$ The optimal clinical management of complement deficiency states is not well defined. Prophylactic antibiotics have not been useful in the prevention of meningococcal disease although appropriateantibiotics are essential for specific infections. Immunizations against $H$. influenzae, $N$. meningitidis, and polyvalent pneumococcal vaccine are recommended. Fresh frozen plasma has also been used during acute infections to replace the deficient components. ${ }^{128} \mathrm{C} 1$ esterase inhibitor deficiency may respond to the use of synthetic androgens such as stanozolol or danazol. ${ }^{132}$

\section{PHAGOCYTIC DEFECTS}

Phagocytic cells have a major function in the lungs scavenging foreign particles, and they are generally responsible for suppression and eradication of microbial growth. The major cells involved are polymorphonuclear leukocytes (PMN) and, to a lesser extent, the eosinophil, basophil, and the alveolar macrophage (AM). There are a small number of neutrophils normally present in the alveolar spaces $\left(<5 \%\right.$ in BAL) ${ }^{133}$ Most PMNs are released from the bone marrow in response to an acute insult. Neutrophils respond to a variety of chemoattractant agents such as those released by mast cells within the alveoli and interstitium and can migrate rapidly to affected areas. The half-life of the neutrophil, once it is extravascular, is 6-24 hours. Powerful PMN chemoattractants include the complement product C5a, other products of complement activation, PAF, and products of arachidonic acid metabolism such as leukotriene $\mathrm{B}_{4}$. The source of macrophages in the lungs is less clear. Macrophages exist in three forms: 1) the alveolar macrophage, 2) the interstitial macrophage, and 3) the circulating blood monocyte. The precise lineage of the alveolar macrophage is unclear, but probably small numbers of monocytes migrate to the lung via the circulation to replenish its population. ${ }^{134}$

The neutrophil's major function is to kill bacteria. This activity is enhanced by its ability to release toxic oxygen radicals and to secrete proteases. The neutrophils contain two main granules: specific and azurophilic. These granules are separated on the basic content, morphology, density, and appearance at different stages of 
neutrophil maturation. ${ }^{135}$ Neutrophils undergo characteristic membrane changes with systematic discharge of their granules during inflammation. Azurophilic and specific granules fuse with phagosomes to form phagolysosomes, discharge their contents, and the phagosome becomes a phagocytic vacuole. Specific granules appear to be necessary for PMN recruitment to sites of inflammation, for regulation of receptors, and they are also important in the control of chemotaxis and the respiratory burst. The azurophilic granule supplies enzymes for bactericidal function and myeloperoxidase (MPO) to the MPO-halide- $\mathrm{H}_{2} \mathrm{O}_{2}$ bactericidal system. The release of toxic oxygen radicals is an important mechanism in cell killing. Free radicals are unstable metabolites of oxygen, which have either received or donated an electron, acting as either oxidizing or reducing agents. Release of toxic oxygen radicals by the PMN can be stimulated by many agents including enzymes and ionizing radiation. In white cells, an NADPH cell membrane oxidase acts as the major source of electrons for the reduction of molecular $\mathrm{O}_{2}$ to $\mathrm{O}_{2}^{-}$(superoxide anion). Superoxide anion can then be further reduced with hydrogen ions present to form hydrogen peroxide $\left(\mathrm{H}_{2} \mathrm{O}_{2}\right) . \mathrm{H}_{2} \mathrm{O}_{2}$ can be further converted to a highly toxic and unstable product, hydroxyl radical $\left(\mathrm{OH}^{-}\right) . \mathrm{H}_{2} \mathrm{O}_{2}$ can also undergo enzyme conversion by MPO in the presence of a halide (i.e., $\mathrm{Cl}^{-}$) forming hypohalous acids and other oxidants. The production and generation of toxic oxygen products involves multiple pathways. ${ }^{136,137}$ Although they are essential for normal defense mechanisms, under certain conditions, toxic oxygen radicals can cause lung injury. The adult respiratory distress syndrome is a prime example of this mechanism. ${ }^{138}$

The functions of the AM are diverse. ${ }^{139}$ The classic function in the lung is the ingestion of inhaled microorganisms and inorganic particles by the process of phagocytosis. AM bear numerous surface receptors to enhance the opsonization process. Other cell surface proteins with important functions are the class I and class II MHC glycoproteins, which are important for B- and T-cell regulation, processing of antigen, and recognition of self. Macrophages also secrete a variety of products which have many regulatory effects on cells. The major enzymes secreted are lysosomal acid, hydrolases, neutral proteases, and lysozyme. Lysozyme is a major secretory product of the macrophage, and it can be found in relatively large amounts in secretions where it is bactericidal for many organisms. ${ }^{140}$ Macrophages are important sources of arachidonic acid metabolites including thromboxane $\mathrm{A}_{2}$, lipoxygenase, and prostaglandins. ${ }^{141} \mathrm{AM}$ produce important immunomodulatory agents such as IL-1 and interferons, which are involved in a variety of functions. The effects of IL-1 include fever induction, fibroblast proliferation, B-cell activation, acute phase reactant synthesis, production of IL-2 by T-cells, and in- creased NK cell function. ${ }^{142}$ Interferons stimulate NK activity and have potent antiviral effects. ${ }^{143}$ Macrophages may also release toxic oxygen radicals albeit less efficiently than neutrophils.

\section{CGD}

CGD is a multisystemic, X-linked or (rarely) autosomal recessive phagocyte disorder associated with granulomatous pyogenic infection. It occurs more commonly as an X-linked disorder and is therefore usually seen in males. It is characterized by defective triggering of oxidative metabolism, and although chemotaxis and phagocytosis are normal, intracellular organisms remain viable due to defective killing. CGD may be due to several disorders affecting oxidative metabolism, ${ }^{144}$ and this may explain the different patterns of inheritance.

Clinically, over $90 \%$ of children manifest their disease by the 2 nd year of life. Widespread organ involvement as a consequence of chronic infection is common. Skin diseases such as eczematoid dermatitis with seborrhea and folliculitis are often associated with staphylococcal pustules and vesicular lesions. Lymphadenopathy and hepatosplenomegaly are very common, and hepatic abscesses are a common complication. Diarrhea with blood and mucus, malabsorption, esophageal malfunction, peptic ulcer, and gastric outlet problems are typical gastrointestinal complications as well as peritonitis, intra-abdominal sepsis, and pararectal abscesses. Osteomyelitis, especially of the small bones of the hands or feet, occurs frequently. Less common sites of infection include the eyes, the pericardium, and the genitourinary tract. Persistent rhinitis and otitis are well described. Sepsis can occur in $11-37 \%$ of patients with a high mortality rate. ${ }^{145}$ Pulmonary disorders are very common in CGD, and over $80 \%$ of patients suffer from recurrent pneumonias. ${ }^{146}$ Hilar lymphadenopathy, empyema, and large pulmonary abscesses are commonly seen. The most common organisms include coagulase positive Staphylococcus aureus and gram negative organisms such as $E$. coli and Klebsiella sp. Infections with Serratia marcescens, Enterobacter sp., Salmonella sp., Proteus, and Pseudomonas are less common. Pseudomonas cepacia, an uncommon pathogen that is seen sometimes in cystic fibrosis, can cause serious infection in CGD. ${ }^{147,148} S$. aureus is the single most common bacterial pathogen. Fungal infections such as Aspergillus, Torulopsis, and Candida occur in $20 \%$ of CGD patients, often in association with pneumonia. ${ }^{149}$ Aspergillus can be isolated in $9 \%$ of patients and can be associated with a diffuse bilateral pneumonia or a localized infection; the mortality of the former is quite high. Pathologically, suppurative granulomata and heavy infiltration with lymphocytes and plasma cells have been reported. ${ }^{150,151}$ Contiguous spread into the chest wall and osteomyelitis have been reported with Aspergillus infection. ${ }^{152}$ Other unusual in- 
fections described include recurrent Nocardia infections, ${ }^{153,154}$ and one case of Neisseria mucosa has been described in a 9-year-old boy. ${ }^{155}$ The phagocytic cells of children with $\mathrm{CGD}$ fail to product toxic $\mathrm{O}_{2}$ derivatives including $\mathrm{H}_{2} \mathrm{O}_{2}$ and $\mathrm{OH}^{-}$radicals. Organisms that produce catalase such as Staphylococcus aureus, Aspergillus fumigatus, E. coli, Pseudomonas, Nocardia, Salmonella, and $N$. mucosa will consume any $\mathrm{H}_{2} \mathrm{O}_{2}$ produced and inhibit microbicidal activity. One case of Legionella pneumophila has also been reported ${ }^{156}$; this organism also produces catalase and a toxin capable of inhibiting the respiratory burst of the neutrophil.

The diagnosis of CGD is based on the inability of the PMN to generate a respiratory burst. The nitroblue tetrazoleum test (NBT) measures the ability of phagocytes to reduce a colorless substance, NBT, to an intracytoplasmic formazan dye. Normally $90 \%$ of PMN accomplish this reduction, compared to only $10 \%$ in CGD patients. Chemiluminescence is the release of light energy from the interaction of free radicals with oxidizable substrates, and it is also reduced in CGD patients. Bactericidal assays of most catalase-positive organisms are specifically reduced.

In CGD, hilar or mediastinal lymph nodes are enlarged radiographically. Large abscesses with empyema are common, and pleural thickening can occur. Extensive reticulonodular infiltration with granulomas has been described, although infection may be initially localized. An encapsulating picture is described where lesions are homogeneous and discrete with a jagged edge. These can occur singly or in massive groups measuring $2-6 \mathrm{~cm} .{ }^{146,157}$ Atelectasis, air bronchograms, and honeycombing are other common changes. Extensive fibrosis, pulmonary infiltrates, honeycombing, and hilar adenopathy have been described without evidence of acute or recent infections. Two cases of bronchopulmonary arterial malformations caused by Aspergillus have been reported. Both patients presented with pneumonia and thoracic bruits present on physical examination; an angiogram was diagnostic. ${ }^{158}$ Gallium $^{67}$ scintigraphy can be useful as an early indicator of pulmonary disease in CGD. ${ }^{159}$

The conventional treatment of CGD includes the aggressive use of both antimicrobial and antifungal agents. Avoidance of a dusty environment, moldy vegetation, and smoking is generally recommended. Prophylactic antibiotics, especially trimethoprim-sulfamethoxazole, have been shown to reduce infections and hospitalizations. The mechanisms proposed include an increase in bactericidal activity, broad spectrum coverage, and selective decontamination of the intestine. ${ }^{160}$ Granulocyte transfusions have significant complications, but they may be helpful for fungal infections, Nocardia and Pneumocystis. ${ }^{161}$ Recently, corticosteroids have been purported to be useful in patients with severe progressive restrictive disease and in patients with a histologic picture of pulmonary lymphocytic infiltration. This form of therapy needs further study, ${ }^{162}$ and caution needs to be used. Steroids should be prescribed only after conventional therapy has failed. Bone marrow transplant has been used to treat the primary white blood cell defect, and this form of therapy may offer a permanent longterm solution, but there are still many problems associated with the procedure. ${ }^{163,164}$

\section{Chediak-Higashi Syndrome (CHS)}

The CHS is a rare lysosomal storage disorder characterized by recurrent pyogenic infections and albinism. CHS almost always occurs in white patients, and consanguinity is present in about one-half of them. Recurrent pyogenic sinopulmonary infections are characteristic including pharyngitis and empyema; skin infections are also common. Oculocutaneous albinism, nystagmus, photophobia, hypersplenism, and an accelerated lymphoma-like phase with a coagulopathy are characteristic findings. The basic defect is unknown, but a pathognomonic histological finding is the presence of giant cells containing inclusion bodies that are the result of abnormal fusion of specific and azurophilic granules. ${ }^{165}$ These giant cells develop in many cell lines including monocytes, melanocytes, neural crest tissue, renal tubular cells, thyroid, and other cell types. Organ dysfunction may be correlated with these cellular abnormalities. Although the giant cells do have a respiratory burst with $\mathrm{H}_{2} \mathrm{O}_{2}$ generation, they fail to discharge their granules into phagocytic vacuoles so that intracellular killing is defective. Other immunological findings include abnormal chemotaxis, possibly caused by intracellular microtubular dysfunction, ${ }^{166}$ and neutropenia caused by hypersplenism, poor mobilization from the bone marrow, or intramedullary destruction. NK cell function and antibody-dependent cytotoxicity (ADCC) are often defective. ${ }^{167-169}$ This abnormality may be responsible for the accelerated phase, which appears to result from inadequate handling of EBV infection. ${ }^{170,171}$ Other infections such as herpes zoster can also be very severe.

There is very little literature on the pulmonary manifestation of CHS. The last major review of these patients reported that otitis, sinusitis, pharyngitis, bronchitis, and pneumonia are common. ${ }^{172}$ The major organisms were $S$. aureus, $H$. influenzae, group A beta hemolytic streptococcus, Klebsiella sp., and pneumococci. The prognosis is very poor with eventual death from infections, from central nervous system deterioration, or from the lymphoma-like accelerated phase. Supportive care with appropriate antibiotics is essential, and a combination of splenectomy, steroids, and antimetabolic drugs may be useful for the accelerated phase. Acyclovir may be useful for selected patients in the accelerated phase. ${ }^{173}$ 


\section{Hyper-IgE Syndrome (HIES)}

The HIES usually presents in a manner similar to a phagocytic cell defect and is characterized by recurrent cold abscesses caused by $S$. aureus, eczematoid skin rashes, cutaneous infections, mucocandidiasis, a widened nasal bridge, coarse facial features, and recurrent sinopulmonary infections. Deep-seated infections, other than pneumonias, are unusual in HIES. Males and females are affected equally with no particular racial distribution. ${ }^{174,175}$ The original description of Job's syndrome affecting fair, red-headed females has since been broadened as these features are not universally present.

The laboratory findings in this illness include markedly elevated IgE levels (generally $\geq 2,000 \mathrm{IU} / \mathrm{mL}$ ), ${ }^{176}$ although lower levels can be seen in children. A low serum IgA value is sometimes found. ${ }^{177}$ Chemotaxis of granulocytes to the chemoattractant agent FMLP is reduced in many patients, ${ }^{178}$ and this originally led to the supposition that the HIES was primarily a white cell disorder. An inhibitor of granulocyte chemotaxis from the supernatants of cultured monocytes has been described in HIES. ${ }^{179}$ Abnormalities of T-suppressor cell regulation of IgE synthesis have also been reported. ${ }^{180}$ Increased production of $\operatorname{IgE}$ antibodies to $S$. aureus and Candida $s p$. may be a unique marker of this disease. ${ }^{181,182}$ Deficiency of serum and salivary anti-S. aureus $\operatorname{IgA}$ antibody has been recently described, but its significance is unclear. ${ }^{177}$ The pulmonary manifestations of HIES are often the most serious and debilitating aspects. The onset is usually in the 1st year of life. Clinically, these patients present with chronic cough and symptoms of bronchitis. Radiographic findings include recurrent pneumonias, abscess formation, empyema, and characteristic findings of pneumatocele and cyst formation. Lung cysts may occasionally resolve spontaneously or they may become superinfected, and lobectomy is sometimes required. The pathogenesis of cyst formation is uncertain since other immunodeficiencies do not usually cause cysts. Cysts containing a dense necrotic layer of exudate with leukocyte infiltration and eosinophils may be found. ${ }^{183}$ The walls of pneumatoceles are usually thin but may thicken with superinfection. Bronchopleural fistulae and intractable pneumothorax are wellrecognized complications; however, bronchiectasis is not very common. Chronic sinusitis, recurrent otitis, dental infections, and mastoiditis are also found in these patients. ${ }^{184}$ The organism usually responsible are $S$. aureus. H. influenzae, Candida, and Aspergillus infection have also been described.

The prognosis of children with the HIES is variable and depends on lung function. Aggressive therapy of sinopulmonary disease with antistaphylococcal antibiotics is critical. ${ }^{174}$

The value of prophylactic antibiotics in HIES is un- certain, but intermittent therapy or continuous treatment with ketoconazole may be useful in the treatment of candidiasis. Levamizole, an immunomodulatory agent, is not felt to be useful. Treatment with ascorbic acid to improve chemotaxis or with cimetidine to block potentially harmful IgE-mediated histamine reactions has not been fully evaluated. Surgical drainage of abscesses is commonly required.

\section{CONCLUSIONS}

In this article we have reviewed the pulmonary manifestations of the primary immune deficiency diseases and the acquired immune deficiency syndrome. It has been estimated that $1-2 \%$ of all chronic respiratory infections are associated with a form of immune deficiency, and it is therefore important to consider these diseases in the differential diagnosis of any child with recurrent respiratory infections as well as in those cases with unusual organisms or a severe clinical picture. It appears that, with the increase in the number of children infected by the human immunodeficiency virus in North America, acquired immune deficiency will become a major clinical challenge to the pulmonologist and the immunologist practicing in pediatric medical centers.

\section{ACKNOWLEDGMENTS}

We thank Daniel Weiner, MS-1, University of Michigan, for editorial assistance, graphics, and word processing.

\section{REFERENCES}

1. Bell DY, Haseman JA, Spock A, McClennan G, Hook GE. Plasma proteins of the bronchoalveolar surface of the lungs of smokers and nonsmokers. Am Rev Respir Dis. 1981; 124:7279.

2. Kaltreider HB. Local immunity. In: Bienenstock J, ed. Immunology of the Lung and Upper Respiratory Tract. New York: McGraw Hill, Inc., 1984:191-215.

3. Crago SS, Kutteh WH, Moro I, Allansmith MR, Radl J, Haaijman JJ, Mestecky J. Distribution of $\operatorname{IgA} A_{1}, \operatorname{Ig} A_{2}$, and $J$ chaincontaining cells in human tissues. J Immunol. 1984; 132:16-18.

4. Underwood BJ. Immunoglobulin A: strategic defense initiative at the mucosal surface. Annu Rev Immunol. 1986; 4:389-417.

5. Buckley RH, Dees SC, O'Fallon WM. Serum immunogloblins: 1. levels in normal children and in uncomplicated childhood allergy. Pediatrics. 1968; 41:600-611.

6. Inoue T, Okubo H, Kudo J, Ikuta T, Hachimine K, Shibata R, Yoshinari $O$, Fukada K, Yanase T. Selective IgA deficiency: analysis of Ig production in vitro. J Clin Immunol. 1984; 4:235241

7. Burks AW, Steele RW. Selective IgA deficiency. Ann Allergy. 1986; 57:3-10.

8. Strober W, Krakauer R, Klaeveman HL, Reynolds HY, Nelson DL. Secretory component deficiency. N Engl J Med. 1976; 294: 351-356. 
9. van Loghem E, Zegers BJM, Bast EJEG, Kater L. Selective deficiency of immunoglobulin A2. J Clin Invest. 1983; 72:19181923.

10. Buckley RH. Clinical and immunologic features of selective IgA deficiency. Birth Defects. 1975; XI:134-142.

11. Zach M. Serum IgA in recurrent croup. Am J Dis Child. 1983; 137:184-185.

12. Chipps BE, Talamo RC, Winkelstein JA. IgA deficiency, recurrent pneumonias and bronchiectasis. Chest. 1978; 4:519-526.

13. Ammann AJ, Hong R. Selective IgA deficiency: Presentation of 30 cases and a review of the literature. Medicine. 1971; 50:223236.

14. Levy J, Wilmott RW. Pulmonary hemosiderosis. Pediatr Pulmonol. 1986; 2:384-391.

15. Polmar SH, Waldmann TA, Balestra ST, Jost MC, Terry WD. Immunoglobin $\mathrm{E}$ in immunologic deficiency diseases $\mathrm{I}$. Relation of $\mathrm{IgE}$ and IgA to respiratory tract disease in isolated IgE deficiency, IgA deficiency and ataxia telangectasia. J Clin Invest. 1972; 51:326-330.

16. Reynolds HY. Lung immunology and its contribution to the immunopathogenesis of certain respiratory diseases. J Allergy Clin Immunol. 1986; 78:833-847.

17. Burks WA, Sampson HA, Buckley RH. Anaphylactic reactions after gamma globulin administration in patients with hypogammaglobulinemia. N Engl J Med. 1986; 9:560-564.

18. Buckley RH. Immunodeficiency. J Allergy Clin Immunol. 1983; 72:627-643.

19. Rosen RS, Cooper MD, Wedgwood RJ. The primary immunodeficiencies. N Engl J Med. 1984; 311:300-310.

20. Huang NN, Laraya-Cuasay L, Huff DS, et al. Pulmonary disease in patients with hypogammaglobulinemia. Chest. 1974; 66:326 (abstr).

21. Lischner HW, Huang NN. Respiratory complications of primary hypogammaglobulinemia. Pediatr Ann. 1977; 6:514-525.

22. Rao CP, Gelfand EW. Pneumocystis carinii penumonitis in patients with hypogammaglobulinemia and intact $\mathrm{T}$ cell immunity. J Pediatr. 1983; 103:410-412.

23. Roifman CM, Levison H, Gelfand EW. High-dose intravenous immunoglobulin in hypogammaglobulinemia and chronic lung disease. Lancet. 1987; 1:1075-1077.

24. Hausser C, Virelizier J-L, Buriot D, Griscelli C. Common variable hypogammaglobulinemia in children. Am J Dis Child. 1983; 137:833--837.

25. Conley ME, Park CL, Douglas SD. Childhood common variable immunodeficiency with autoimmune disease. J Pediatr. 1986; 108:915-922.

26. Dawson J, Hodgson HJ, Pepys MB, Peters TJ, Chadwick VS. Immunodeficiency, malabsorption and secretory diarrhea. Am J Med. 1979; 67:540-546.

27. Siegal FP, Siegal M, Good RA. Role of helper, suppressor, and B-cell defects in the pathogenesis of the hypogammaglobulinemias. N Engl J Med. 1978; 299:172-178.

28. Vermess M, Waldmann TA, Pearson KD. Radiographic manifestations of primary acquired hypogammaglobulinemia. Radiology. 1973; 107:63-69.

29. Dukes RJ, Rosenow III EC, Hermans PE. Pulmonary manifestations of hypogammaglobulinaemia. Thorax. 1978; 33:603607.

30. Douglas SD, Goldberg LS, Fudenberg HH. Clinical, serologic and leukocyte function studies in patients with idiopathic "acquired" agammaglobulinemia and their families. Am J Med. $1970 ; 48: 48-53$.

31. Watts WJ, Watts MB, Dai W, Cassidy JT, Grum CM, Weg JG. Respiratory dysfunction in patients with common variable hy- pogammaglobulinemia. Am Rev Respir Dis. 1986; 134:699703.

32. Lederman HM, Gelfand EW. Immune deficiency and the immunocompromised host. In: Bienenstock J, ed. Immunology of the Lung and Upper Respiratory Tract. New York: McGraw Hill, Inc., 1984:311-325.

33. Friedman R, Ackerman M, Mallory G, Weng TR, Fireman P. Hypogammaglobulinemia with sarcoidlike granulomas. Am J Dis Child. 1983; 137:774-776.

34. Popa V. Lymphocytic interstitial pneumonia of common variable immunodeficiency. Ann Allergy. 1988; 60:203-206.

35. Kohler PF, Cook RD, Brown WR, Manguso RL. Common variable hypogammaglobulinemia with $\mathrm{T}$-cell nodular lymphoid interstitial pneumonitis and B-cell nodular lymphoid hyperplasia: Different lymphocyte populations with a similar response to prednisone therapy. J Allergy Clin Immunol. 1982; 70:299305.

36. Levinson AI, Hopewell PC, Stites DP, Spitler LE, Fudenberg HH. Coexistent lymphoid interstitial pneumonia, pernicious anemia, and agammaglobinemia. Arch Intern Med. 1976; 136: 213-216.

37. Corkey CW, Gelfand EW. Hypogammaglobulinemia and antibody deficiency in patients with elevated sweat chloride concentrations. J Pediatr. 1982; 100:420-422.

38. Schur P. IgG subclasses-a review. Ann Allergy. 1987; 58:89100.

39. Berger $M$. Immunoglobulin $G$ subclass determination in diagnosis and management of antibody deficiency syndromes. J Pediatr. 1987; 110:325-328.

40. Umetsu DT, Ambrosino DM, Quinti I, Siber GR, Geha RS. Recurrent sinopulmonary infection and impaired antibody response to bacterial capsular polysaccharide antigen in children with selective IgG-subclass deficiency. N Engl J Med. 1985; 313:1247-1251.

41. Björkander J, Bake B, Oxelius V-A, Hanson LA. Impaired lung function in patients with IgA deficiency and low levels of $\operatorname{IgG}_{2}$ or $\mathrm{IgG}_{3}$. N Engl J Med. 1985; 313:720-724.

42. Smith TF, Morris EC, Bain RP. IgG subclasses in nonallergic children with chronic chest symptoms. J Pediatr. 1984; 105:896900.

43. Shackelford PG, Polmar SH, Mayus JL, Johnson WL, Corry $\mathrm{JM}, \mathrm{Nahm} \mathrm{MH}$. Spectrum of $\mathrm{IgG}_{2}$ subclass deficiency in children with recurrent infections: Prospective study. J Pediatr. 1986; 108:647-653

44. Oxclius V-A, Laurell A-B, Lindquist B, Golebiowska H, Axelsson $\mathrm{U}$, Bjorkander J, Hanson LA. IgG subclasses in selective IgA deficiency. N Engl J Med. 1981; 304:1476-1477.

45. Beck CS, Heiner DC. Selective immunoglobulin $\mathrm{G}_{4}$ deficiency and recurrent infections of the respiratory tract. Am Rev Respir Dis. 1981; 124:94-96.

46. Heiner DC. Recognition and management of IgG subclass deficiencies. Pediatr Infect Dis J. 1987; 6:235-238.

47. Siegel RL, Issekutz T, Schwaber J, Rosen RS, Geha RS. Deficiency of $\mathrm{T}$ helper cells in transient hypogammaglobulinemia of infancy. N Engl J Med. 1981; 305:1307-1313.

48. McGeady SJ. Transient hypogammaglobulinemia of infancy: Need to reconsider name and definition. J Pediatr. 1987; 110:4750 .

49. Tiller TL, Buckley RH. Transient hypogammaglobulinemia of infancy: Review of the literature, clinical and immunological features of 11 new cases, and long-term follow up. J Pediatr. 1978; 92:347-353.

50. Hirschhorn R. Adenosine deaminase deficiency. Hosp Pract [off]. 1987; 22:83-90.

51. Rijksen G, Kuis W, Wadman SK, Spaapen LJ, Duran M, Voor- 
brood BS, Staal GE, Stoop JW, Zegers BJ. A new case of purine nucleoside phosphorylase deficiency: Enzymologic, clinical, and immunologic characteristics. Pediatr Res. 1987; 21:137141.

52. Simmonds HA, Fairbanks LD, Morris GS, Morgan G, Watson AR, Timms P, Singh B. Central nervous dysfunction and erythrocyte guanosine triphosphate depletion in purine nucleoside phosphorylase deficiency. Arch Dis Child. 1987; 62:385-391.

53. Leggiadro RJ, Winkelstein JA, Hughes WT. Prevalence of pneumocystis carinii pneumonitis in severe combined immunodeficiency. J Pediatr. 1981; 99:96-98.

54. Walzer PD, Schultz MG, Western KA, Robbins JB. Pneumocystis carinii pneumonia and primary immune deficiency diseases of infancy and childhood. J Pediatr. 1973; 82:416-422.

55. Jarvis WR, Middleton PJ, Gelfand EW. Significance of viral infections in severe combined immunodeficiency disease. Pediatr Infect Dis J. 1983; 2:187-192.

56. Fishaut $M$, Tubergen D, McIntosh $\mathrm{K}$. Cellular response to respiratory viruses with particular reference to children with disorders of cell-mediated immunity. J Pediatr. 1980; 96:179-186.

57. Jarvis WR, Middleton PJ, Gelfand EW. Parainfluenza pneumonia in severe combined immunodeficiency disease. J Pediatr. $1979 ; 94: 423-425$.

58. Karp D, Willis J, Wilfert CM. Parainfluenza virus II and the immunocompromised host. Am J Dis Child. 1974; 127:592593.

59. Frank JA, Warren RA, Tucker JA, Zeller J, Wilfert CM. Disseminated parainfluenza infection in a child with severe combined immunodeficiency. Am J Dis Child. 1983; 137:11721174.

60. Milner ME, de la Monte SM, Hutchins GM. Fatal respiratory syncytial virus infection in severe combined immunodeficiency syndrome. Am J Dis Child. 1985; 139:1111-1115.

61. Dagan R, Schwartz RH, Insel RA, Menegus MA. Severe diffuse adenovirus 7 a pneumonia in a child with combined immunodeficiency: Possible therapeutic effect of human immune serum globulin containing specific neutralizing antibody. Pediatr Infect Dis J. 1984; 3:246-251.

62. Delage G, Brochu P, Pelletier M, Jasmin G, LaPointe N. Giantcell pneumonia caused by parainfluenza virus. J Pediatr. 1979; 94:426-429.

63. Delage G, Brochu P, Robillard L, Jasmin G, Joncas JH, Lapointe N. Giant-cell pneumonia due to respiratory syncytial virus: Occurence in severe combined immunodeficiency syndrome. Arch Pathol Lab Med. 1984; 108:623-625.

64. Cutz E, Thorner PS, Rao CP, Toma S, Gold R. Disseminated Legionella pneumophilia infection in an infant with severe combined immunodeficiency. J Pediatr. 1982; 100:760-762.

65. Buckley RH, Schiff SE, Sampson HA, Schiff RI, Markert ML, Knutsen AP, Mershfield MS, Huang AT, Mickey GH, Ward FE. Development of immunity in human severe primary $T$ cell deficiency following haploidentical bone marrow stem cell transplantation. J Immunol. 1986; 136:2398-2407.

66. Polmar SH, Stern RC, Schwartz AL, Wetzler EM, Chase PA, Hirschhorn R. Enzyme replacement therapy for adenosine deaminase deficiency-deficient patient with severe combined immunodeficiency. N Engl J Med. 1976; 295:1337-1343.

67. McIntosh K, Kurachek SC, Cairns LM, Burns JC, Goodspeed $B$. Treatment of respiratory viral infection in an immunodeficient infant with ribavirin aerosol. Am J Dis Child. 1984; 138 : 305-308.

68. Berseth $\mathrm{CL}$. Is there an acquired immune deficiency syndrome in children? Pediatrics. 1983; 72:430-431.

69. Ferrieri D. AIDS, children and primary care physicians. Am J Dis Child. 1988; 142:272.
70. Ho DD, Pomerantz RJ, Kaplan JC. Pathogenesis of infection with human immunodeficiency virus. N Engl J Med. 1987; 317 : $278-286$.

71. Kamani N, Krilov L. AIDS and the spectrum of human immunodeficiency virus infection in children. Pediatr Rev Commun. 1987; 1:101-121.

72. Bernstein LJ, Ochs HD, Wedgwood RJ, Rubinstein A. Defective humoral immunity in pediatric acquired immune deficiency syndrome. J Pediatr. 1985; 107:352-357.

73. Barbour SD. Acquired immunodeficiency syndrome in childhood. Pediatr Clin North Am. 1987; 34:247-268.

74. Bye MR, Bernstein L, Shah K, Ellaurie M, Rubinstein A. Diagnostic bronchoalveolar lavage in children with AIDS. Pediatr Pulmonol. 1987; 3:425-428.

75. Murray JF, Felton CP, Garay SM, Gottlieb MS, Hopewell PC, Stover DE, Teirstein AS. Pulmonary complications of the acquired immunodeficiency syndrome: Report of a National Heart, Lung, and Blood Institute workshop. N Engl J Med. 1984; 310: 1682-1688.

76. Glatt AE, Chirgwin K, Landesman SH. Treatment of infections associated with human immunodeficiency virus. N Engl J Med. 1988; 318:1439-1448.

77. Fournier AM, Dickinson GM, Erdfrocht IR, Cleary T, FischI MA. Tuberculosis and nontuberculous mycobacteriosis in patients with AIDS. Chest. 1988; 93:772-775.

78. Wasser L, Talavera W. Pulmonary cryptococcosis in AIDS. Chest. 1987; 92:692-695.

79. Hopewell PC, Luce JM. Pulmonary involvement in the acquired immunodeficiency syndrome. Chest. 1985; 87:104-112.

80. Marchevsky A, Rosen MJ, Chrystal G, Kleinerman J. Pulmonary complications of the acquired immunodeficiency syndrome: A clinicopathologic study of 70 cases. Hum Pathol. $1985 ; 16: 659-670$.

81. Rubinstein A, Morecki R, Silverman B, Charytan M, Krieger BZ, Andiman W, Zigrkowski MN, Goldman H. Pulmonary disease in children with acquired immune deficiency syndrome and AIDS-related complex. J Pediatr. 1986; 108:498-503.

82. Andiman WA, Eastman R, Martin K, Katz BZ, Rubinstein A, Pitt J, Pahwa S, Miller G. Opportunistic lymphoproliferations associated with Epstein-Barr viral DNA in infants and children with AIDS. Lancet. 1985; 2:1390-1393.

83. Silverman BA, Rubinstein A. Serum lactate dehydrogenase levels in adults and children with acquired immune deficiency syndrome (AIDS) and AIDS-related complex: Possible indicator of B cell lymphoproliferation and disease activity: Effect of intravenous gammaglobulin on enzyme levels. Am J Med. 1985; 78:728-736.

84. Grieco MH, Chinoy-Acharya P. Lymphocytic interstitial pneumonia associated with the acquired immune deficiency syndrome. Am Rev Respir Dis. 1985; 131:952-955.

85. Solal-Celigny $P$, Couderc LJ, Herman D, Herve P, SchaffarDeshayes L, Brun-Vezinet F, Tricot G, Clauvel JP. Lymphoid interstitial pneumonitis in acquired immunodeficiency syndrome-related complex. Am Rev Respir Dis. 1985; 131:956960.

86. Joshi VV, Oleske JM, Minnefor AB, Singh R, Bokhari T, Rapkin RH. Pathology of suspected acquired immune deficiency syndrome in children: A study of eight cases. Pediatr Pathol. 1984; 2:71-87.

87. Joshi VV, Oleske JM, Minnefor AB, Saad S, Klein KM, Singh R, Zabala M, Dadzie M, Simpsen M, Rapkin RH. Pathologic pulmonary findings in children with the acquired immunodeficiency syndrome: A study of ten cases. Hum Pathol. 1985; 16:241246.

88. Schiff RG, Kabat L, Kamani N. Gallium scanning in lymphoid 
interstitial pneumonitis of children with AIDS. J Nucl Med. 1987; 28:1915-1919.

89. Vernon DD, Holzman BH, Lewis P, Scott GB, Birriel JA, Scott $M B$. Respiratory failure in children with acquired immunodeficiency syndrome and acquired immunodeficiency syndrome-related complex. Pediatrics. 1988; 82:223-228.

90. Rubinstein A, Bernstein LJ, Charytan M, Krieger BZ, Ziprkowski M. Corticosteroid treatment for pulmonary lymphoid hyperplasia in children with the acquired immune deficiency syndrome. Pediatr Pulmonol. 1988; 4:13-17.

91. Gordin FM, Simon GL, Wofsy CB, Mills J. Adverse reactions to trimethoprim-sulfamethoxazole in patients with the acquired immunodeficiency syndrome. Ann Intern Med. 1984; 100:495499.

92. Young K, Bailey W. Non-TB mycobacterial infections: a rapidly increasing danger. J Respir Dis. 1988; 9:20-34

93. Kiel EA, Drummond WH, Barrett DJ. Prevalence of T-lymphocyte abnormalities in infants with congenital heart disease. Am J Dis Child. 1984; 138:143-146.

94. Conley ME, Beckwith JB, Mancer JFK, Tenckhoff $L$. The spectrum of the DiGeorge syndrome. J Pediatr. 1979; 94:883-890.

95. Kelley RI, Zackai EH, Emanuel BS, Kistenmacher M, Greenberg F, Punnet HH. The association of the DiGeorge anomalad with partial monosomy of chromosome 22. J Pediatr. 1982; 101:197-200.

96. Barrett DJ, Ammann AJ, Wara DW, Cowan MJ, Fisher TJ, Stiehm ER. Clinical and immunological spectrum of the DiGeorge syndrome. J Clin Lab Immunol. 1981; 6:1-6.

97. Lischner HW, Huff DS. T-cell deficiency in DiGeorge syndrome. Birth Defects. 1975; XI:16-21.

98. Goldsobel AB, Haas A, Stiehm ER. Bone marrow transplantation in DiGeorge syndrome. J Pediatr. 1987; 111:40-44.

99. McFarlin DE, Strober W, Waldmann TA. Ataxia telangiectasia. Medicine. 1972; 51:281-314.

100. Jason JM, Gelfand EW. Diagnostic considerations in ataxiatelangiectasia. Arch Dis Child. 1979; 54:682-686.

101. Swift M, Sholman L, Perry M, Chase C. Malignant neoplasms in the families of patients with ataxia telangiectasia. Cancer Res. 1976; 36:209-215.

102. Waldmann TA, McIntire KR. Serum-alpha-fetoprotein levels in patients with ataxia-telangiectasia. Lancet. 1972; 2:1112-1115.

103. Oxelius V-A, Berkel AI, Hanson LA. IgG deficiency in ataxiatelangiectasia. N Engl J Med. 1982; 306:515-517.

104. Pillsbury LH, Peters SM, Wientzen RL, Phillips T, Papadopoulou ZL, Bellanti JA. Ataxia telangiectasia: Immunologically mediated renal and hepatic failure. Ann Allergy. 1985; 55:593598.

105. Ammann AJ, Cain WA, Ishizaka K, Hong R, Good RA. Immunoglobulin $\mathrm{E}$ deficiency in ataxia-telangiectasia. N Engl J Med. 1969; 281:469-472.

106. Saxon A, Stevens RH, Golde DW. Helper and suppressor Tlymphocyte leukemia in ataxia-telangiectasia. $\mathbf{N}$ Engl $\mathbf{J}$ Med. 1979; 300:700-704.

107. Yount WJ. $\operatorname{IgG}_{2}$ deficiency and ataxia telangiectasia. N Engl J Med. 1982; 306:541-542.

108. Wolff JA. Wiskott-Aldrich syndrome: Clinical, immunologic and pathologic observations. J Pediatr. 1967; 70:221-232.

109. Gröttum KA, Hovig T, Holmsen H, Abrahamsen AF, Jeremic M, Seip M. Wiskott-Aldrich syndrome: Qualitative platelet defects and short platelet survival. Br J Haematol. 1969; 17:373388.

110. Cooper MD, Chase HP, Lowman JT, Krivit W, Good RA. Wiskott-Aldrich syndrome: An immunologic deficiency disease involving the afferent limb of immunity. Am J Med. 1968; 44:499513.
111. Diaz-Buxo JA, Hermans PE, Ritts RE. Wiskott-Aldrich syndrome in an adult. Mayo Clinic Proc. 1974; 49:455-459.

112. Blaese RM, Brown RS, Strober W, Waldemann TA. The Wiskott-Aldrich syndrome: A disorder with a possible defect in antigen processing or recognition. Lancet. 1968; 1:1056-1061.

113. Blaese RM, Strober W, Levy AL, Waldemann TA. Hypercatabolism of IgG, IgA, IgM, and albumin in the Wiskott-Aldrich syndrome. A unique disorder of serum protein metabolism. J Clin Invest. 1971; 50:2331-2338.

114. St. Geme JW, Prince JT, Burke BA, Good RA, Krivit W. Impaired cellular resistance to herpes-simplex virus in WiskottAldrich syndrome. N Engl J Med. 1965; 273:229-234.

115. Perry GS, 3d, Spector BD, Schuman LM, Mandel JS, Anderson VE, McHugh RB, Hanson MR, Fahlstrom SM, Krivit W, Kersey JH. The Wiskott-Aldrich syndrome in the United States and Canada (1892-1979). J Pediatr. 1980; 97:72-78.

116. Meuwissen HJ, Bortin MM, Bach FH, Porter IH, Schreinmachers D, Harrison BA, Taft E. Long term survival after bone marrow transplantation: A 15 year follow-up report of a patient with Wiskott-Aldrich syndrome. J Pediatr. 1984; 105:365-369.

117. Spitler LE. Transfer factor therapy in the Wiskott-Aldrich syndrome: Results of long term follow-up in 32 patients. Am J Med. $1979 ; 67: 59-66$.

118. Muller-Eberhard HJ. Complement. Annu Rev Biochem. 1975; 44:697-724.

119. Fearon DT. Complement. J Allergy Clin Immunol. 1983; 71:520529.

120. Frank MM. Complement in the pathophysiology of human disease. N Engl J Med. 1987; 316:1525-1530.

121. Ross SC, Densen P. Complement deficiency states and infection: Epidemiology, pathogenesis and consequences of neisserial and other infections in an immune deficiency. Medicine. 1984; 63: 243-273.

122. Garty B-Z, Conley ME, Douglas SD, Kolski GB. Recurrent infections and staphylococcal liver abscess in a child with $\mathrm{C} 1 \mathrm{r}$ deficiency. J Allergy Clin Immunol. 1987; 80:631-635.

123. Legendre M, Chiche JF, Molina C, Grouffal C, Betail G. Respiratory manifestations of hereditary angioneurotic oedema. Rev Pneumol Clin. 1985; 41:251-258

124. Alsenz J, Bork K, Loos M. Autoantibody-mediated acquired deficiency of $\mathrm{Cl}$ inhibitor. $\mathrm{N}$ Engl $\mathrm{J}$ Med. 1987; 316:13601366.

125. Fields T, Ghebrehiwet DVM, Kaplan AP. Kinin formation in hereditary angioedema plasma: evidence against kinin derivation from C2 and in support of "spontaneous" formation of bradykinin. J Allergy Clin Immunol. 1983; 72:54-60.

126. Borzy MS, Gewurz A, Wolff L, Houghton D, Lovrien E. Inherited $\mathrm{C} 3$ deficiency with recurrent infections and glomerulonephritis. Am J Dis Child. 1988; 142:79-83.

127. McLean RH, Winkelstein JA. Genetically determined variation in the complement system: Relationship to disease. J Pediatr. $1984 ; 105: 179-188$.

128. Fries LF, O'Shea JJ, Frank MM. Inherited deficiencies of complement and complement-related proteins. Clin Immunol Immunopathol. $1986 ; 40: 37-49$.

129. Gross GN, Rehm SR, Pierce AK. The effect of complement depletion on lung clearance of bacteria. J Clin Invest. 1978; 62:373-378.

130. Cerquetti MC, Sordelli DO, Ortegon RA, Bellanti JA. Impaired lung defenses against staphylococcus aureus in mice with hereditary deficiency of the fifth component of complement. Infect Immun. 1983; 41:1071-1076.

131. Coonrod JD, Yoneda K. Comparitive role of complement in pneumococcal and staphylococcal pneumonia. Infect Immun. $1982 ; 37: 1270-1277$. 
132. Williams LW, Burk AW, Steele RW. Complement: Function and clinical relevance. Ann Allergy. 1988; 60:293-300.

133. Hunninghake GW, Gadek JE, Kawanami O, Ferrans VJ, Crystal RG. Inflammatory and immune processes in the human lung in health and disease: Evaluation by bronchoalveolar lavage. Am J Pathol. 1979; 97:149-206.

134. Musson RA, Henson PM. Phagocytic cells. In: Bienenstock J, ed. Immunology of the Lung and Upper Respiratory Tract. New York: McGraw Hill, Inc., 1984:119-138.

135. Falloon J, Gallin JI. Neutrophil granules in health and disease. J Allergy Clin Immunol. 1986; 77:653-662.

136. Fantone JC, Feltner DE, Brieland JK, Ward PA. Phagocytic cell-derived inflammatory mediators and lung disease. Chest. 1987; 91:428-435.

137. Ward PA. Host-defense mechanisms responsible for lung injury J Allergy Clin Immunol. 1986; 78:373-378.

138. Brigham $\mathrm{KL}$. Role of free radicals in lung injury. Chest. 1986; 89:859-863.

139. Herscowitz HB. In defense of the lung: Paradoxical role of the pulmonary alveolar macrophage. Ann Allergy. 1985; 55:634650 .

140. Fels AO, Zanvil ZA. The alveolar macrophage. J Appl Physiol. $1986 ; 60: 353-369$.

141. Henderson WR. Lipid-derived and other chemical mediators of inflammation of the lung. J Allergy Clin Immunol. 1987; 79:543555.

142. Dinarello CA. Interleukin-1. Rev Infect Dis. 1984; 6:51-95.

143. Trinchieri G, Perussia B. Immune interferon: A pleiotropic lymphokine with multiple effects. Immunol Today. 1985; 6:131136.

144. Quie PG. Phagocytic cell dysfunction. J Allergy Clin Immunol. 1986; 77:387-398.

145. Donowitz GR, Mandell GL. Clinical presentations and unusual infections in chronic granulomatous disease. In: Gallin JI, Fauci AS, eds. Advances in Host Defense Mechanisms. New York: Raven Press, 1983:55-75.

146. Gold RH, Douglas SD, Preger L, Steinbach HL, Fudenberg HH. Roentgenographic features of the neutrophil dysfunction syndromes. Radiology. 1969; 92:1045-1054.

147. Clegg HW, Newburger PE. Pseudomonas cepacia pneumonia in chronic granulomatous disease. Pediatr Infect Dis. 1986; 5:111.

148. Bottone EJ, Douglas SD, Rausen AR, Keusch GT. Association of $P$ seudomonas cepacia with chronic granulomatous disease. $J$ Clin Microbiol. 1975; 1:425-428.

149. Cohen MS, Isturiz RE, Malech HL, Root RK, Wilfert CM, Gutman L, Buckley RH. Fungal infections in chronic granulomatous disease. Am J Med. 1981; 71:59-66.

150. Kelly JK, Pinto AR, Whitelaw WA, Ronstad OP, Bowen TJ, Matheson DS. Fatal aspergillus pneumonia in chronic granulomatous disease. Am J Clin Pathol. 1986; 86:235-240.

151. Schoumacher RA, Berkow RL. Invasive pulmonary aspergillosis in an infant: An unusual presentation of chronic granulomatous disease. Pediatr Infect Dis. 1987; 6:215-217.

152. Gaisie G, Bowen A, Quattromani FL, Oh KS. Chest wall invasion by aspergillus in chronic granulomatous disease of childhood. Pediatr Radiol. 1981; 11:203-206.

153. Jonsson S, Wallace RJ, Hull SI, Musher DM. Recurrent nocardia pneumonia in an adult with chronic granulomatous disease. Am Rev Respir Dis. 1986; 133:932-934.

154. Casale TB, Macher AM, Fauci AS. Concommitant pulmonary aspergillosis and nocardiosis in a patient with chronic granulomatous disease of childhood. South Med J. 1984; 77:274-275.

155. Claassen JL, Eppes SC, Buckley RH. Pulmonary coin lesion caused by Neisseria mucosa in a child with chronic granulomatous disease. Pediatr Infect. Dis. 1987; 6:567-569.
156. Peerless AG, Liebhaber M, Anderson S, Lehrer RI, Stiehm ER. Legionella pneumonia in chronic granulomatous disease. $\mathrm{J} \mathrm{Pe}$ diatr. 1985; 106:783-785.

157. Wolfson JJ, Quie PG, Laxdal SD, Good RA. Roentgenologic manifestations in children with a genetic defect of polymorphonuclear leukocyte function. Radiology. 1968; 91:37-48.

158. Wiseman NE, Reed MH. Bronchopulmonary arterial malformation occurring in aspergillus lung infection complicating chronic granulomatous disease. J Pediatr Surg. 1981; 16:457-460.

159. Papanicolaou N, Curnette JT, Nathan DG, Treves S. Gallium-67 scintigraphy in children with chronic granulomatous disease. Pediatr Radiol. 1983; 13:137-140.

160. Weening RS, Kabel P, Pijman P, Roos D. Continuous therapy with sulfamethoxazole-trimethoprim in patients with chronic granulomatous disease. J Pediatr. 1983; 103:127-130.

161. van der Meer JW, van den Broek PJ. Present status of the management of patients with defective phagocytic function. Rev Infect Dis. 1984; 6:107-119.

162. Quie PG, Belani KK. Corticosteroids for chronic granulomatous disease. J Allergy Clin Immunol. 1987; 111:393-394.

163. Rappaport JM, Newburger PE, Goldblum RM, Goldman AS, Nathan DG, Parkman R. Allogeneic bone marrow transplantation for chronic granulomatous disease. J Pediatr. 1982; 101:952955.

164. Kamani N, August CS, Douglas SD, Burkey E, Etzioni A, Lischner HW. Bone marrow transplantation in chronic granulomatous diseases. J Pediatr. 1984; 105:42-46.

165. Rausch PG, Pryzwansky KB. Immunocytochemical identification of azurophilic and specific granule markers in the giant granules of Chediak-Higashi neutrophils. N Engl J Med. 1978; 298:693-698.

166. Clark RA, Kimball HR. Defective granulocyte chemotaxis in the Chediak-Higashi syndrome. J Clin Invest. 1971; 50:26452652.

167. Haliotis T, Roder J, Klein M, Ortaldo J, Fauci AS, Heberman RB. Chediak-Higashi gene in humans. I. impairment of naturalkiller function. J Exp Med. 1980; 151:1039-1048.

168. Klein M, Roder J, Haliotis T, Korec S, Jeff JR, Herberman RB, Katz P, Fauci AS. Chediak-Higashi gene in humans II. The selectivity of the defect in natural killer and antibody-dependent cell-mediated cytotoxicity function. J Exp Med. 1980; 151:10491058.

169. Katz P, Zaytoun AM, Fauci AS. Deficiency of active natural killer cells in the Chediak-Higashi syndrome. J Clin Invest. 1982; 69:1231-1238.

170. Vilmer E, Lenoir GM, Virelizier JL. Epstein-Barr serology in immunodeficiencies: an attempt to correlate with immune abnormalities in Wiskott-Aldrich and Chediak-Higashi syndromes and ataxia telangiectasia. J Exp Immunol. 1984; 55:249-256.

171. Merino F, Klein GO, Henle W, Ramirez-Duque P, Forsgren M, Amesty C. Elevated antibody titers to Epstein-Barr virus and low natural killer cell activity in patients with Chediak-Higashi syndrome. Clin Immunol Immunopathol. 1983; 27:326-339.

172. Blume RS, Wolff SM. The Chediak-Higashi syndrome: Studies in four patients and a review of the literature. Medicine. 1972; $51: 247-280$.

173. Sullivan JL, Medveczky P, Forman SJ, Baker SM, Monroe JE, Mulder C. Epstein-Barr-virus induced lymphoproliferation. N Engl J Med. 1984; 311:1163-1167.

174. Donabedian H, Gallin JI. The hyperimmunoglobulin E recurrent-infection (Job's) syndrome. Medicine. 1983; 62:195-208.

175. Douglas SD, Campbell DE. The hyperimmunoglobulin E-recurrent infection syndrome. Clin Immunol Newsletter. 1984; $5: 86-87$. 
176. Buckley RH, Wray BB, Belmaker EZ. Extreme hyperimmunoglobulin $\mathrm{E}$ and undue susceptibility to infection. Pediatrics. 1972; 49:59-70.

177. Dreskin SC, Goldsmith PK, Gallin JI. Immunoglobulins in the hyperimmunoglobulin E and recurrent infection (Job's) syndrome. J Clin Invest. 1985; 75:26-34.

178. Hill HR, Ochs HD, Quie PG, Clark RA, Pabst HF, Klebanoff SJ, Wedgwood RJ. Defect in neutrophil granulocyte chemotaxis in Job's syndrome of recurrent "cold" staphylococcal abscesses. Lancet. 1974; 2:617-619.

179. Donabedian H, Gallin JI. Two inhibitors of neutrophil chemotaxis are produced by hyperimmunoglobulin $\mathrm{E}$ recurrent infection syndrome mononuclear cells exposed to heat-killed staphylococci. Infect Immun. 1983; 40:1030-1037.

180. Geha RS, Reinherz E, Leung D, McKee KT Jr, Schlossman $S$, Rosen FS. Deficiency of suppressor $T$ cells in the hyper- immunoglobulin E syndrome. J Clin Invest. 1981; 68:783791.

181. Schopfer K, Baerlocher K, Price P, Krech U, Quie PG, Douglas SD. Staphylococcal IgE antibodies, hyperimmunoglobulinemia $\mathrm{E}$ and staphylococcus aureus infections. N Engl J Med. 1979; 300:835-838.

182. Berger M, Kirkpatrick CH, Goldsmith PK, Gallin JI. IgE antibodies to staphylococcus aureus and candida albicans in patients with the syndrome of hyperimmunoglobulin $\mathrm{E}$ and recurrent infections. J Immunol. 1980; 125:2437-2443.

183. Merten D, Buckley RH, Pratt PC, Effmann EL, Grossman H. Hypcrimmunoglobinemia E syndrome: Radiographic observations. Radiology. 1979; 132:71-78.

184. Fitch SJ, Magill HL, Herrod HG, Moinuddin M. Hyperimmunoglobulin E syndrome: Pulmonary imaging considerations. Pediatr Radiol. 1986; 16:285-288. 